UCRL-CR-132142 Vol. 1

\title{
Rapid Deployment Drilling System For On-Site Inspections Under A Comprehensive Test Ban Treaty
}

- Vol. 1: Description, Acquisition, Deployment, and Operation -

\author{
John Cohen \\ Gerard Pittard \\ Greg Deskins \\ Maurer Engineering Inc., Houston, TX
}

Devin Rock

Paul Vorkinn

Schlumberger Oilfield Services, Sugar Land, TX

Francois Heuze,

Lawrence Livermore National Laboratory, Livermore, CA

This report was prepared for the U.S. Department of Energy's

Office of Non-Proliferation and National Security

January, 1999 
This document was prepared as an account of work sponsored by an agency of the United States Government. Neither the United States Government nor the University of California nor any of their cmployees, makes any warranty, express or implied, or assumes any legal liability or responsibility for the accuracy, completeness, or usefulness of any information, apparatus, product, or process disclosed, or represents that its use would not infringe privately owned rights. Reference herein to any specific commercial product, process, or service by trade name, trademark, manufacturer, or otherwise, does not necessarily constitute or imply its endorsement, recommendation, or favoring by the United States Government or the University of California. The views and opinions of authors expressed herein do not necessarily state or reflect those of the United States Government or the University of California and shall not be used for advertising or product endorsement purposes.

Work performed under the auspices of the U.S. Department of Energy by Lawrence Livermore National Laboratory under Contract W-7405-ENG-48. 


\section{TABLE OF CONTENTS}

VOLUME 1

Page

1. INTRODUCTION $\ldots \ldots \ldots \ldots \ldots \ldots \ldots \ldots \ldots \ldots \ldots \ldots \ldots \ldots \ldots \ldots \ldots \ldots \ldots \ldots \ldots \ldots$

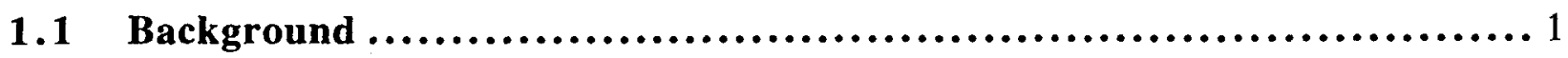

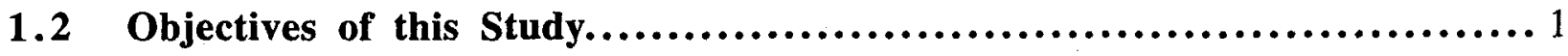

2. RDDS TECHNICAL DESCRIPTION..............................

2.1 Coiled-tubing Unit...........................................

2.2 Drilling Mast/Injector Handling System $\ldots \ldots \ldots \ldots \ldots \ldots \ldots \ldots \ldots \ldots \ldots$

2.3 Drilling Fluid Handling System $\ldots \ldots \ldots \ldots \ldots \ldots \ldots \ldots \ldots \ldots \ldots \ldots \ldots \ldots$

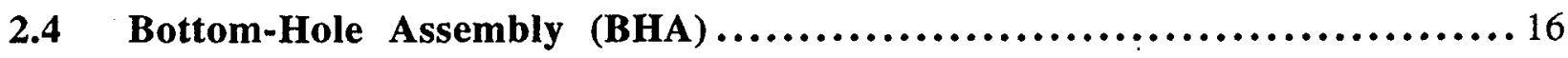

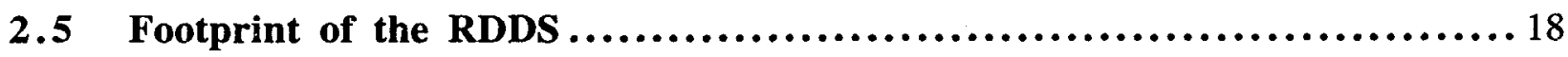

3. COSTS OF ACQUISITION AND OPERATION...................... 20

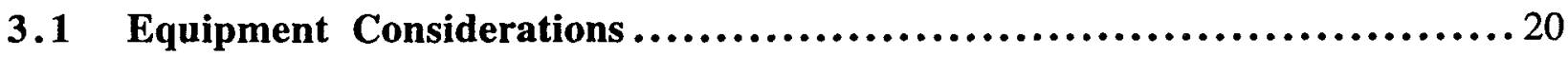

3.2 Purchase Costs................................................ 20

3.3 Rental Costs................................................. 21

3.4 Timing and Contractual Considerations...........................23

3.5 Personnel..................................................... 23

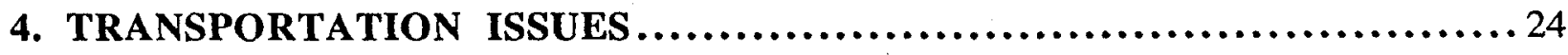

5. LABORATORY DRILLING TEST................................ 27

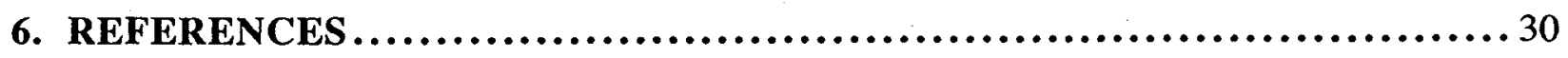

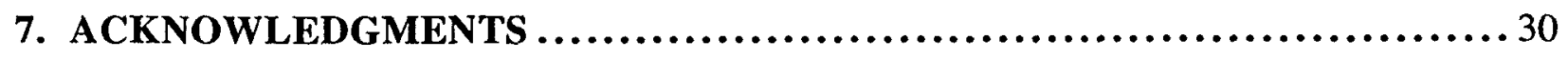


VOLUME 2

APPENDIX A: Stewart and Stevenson - Coiled-Tubing Quotation

APPENDIX B: Tri-Flow International Inc. - MUD System Quotation

APPENDIX C: Clearwater Inc. - Air/Mist/Foam System Quotation

APPENDIX D: Maurer Engineering - MUDLITE Computer Model Output

APPENDIX E: Maurer Engineering - Drilling Test Data 


\section{LIST OF FIGURES}

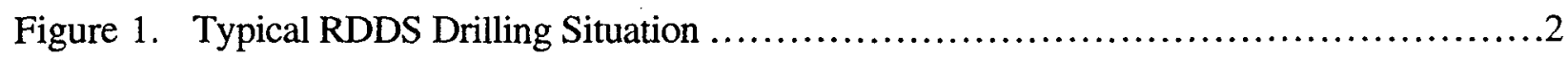

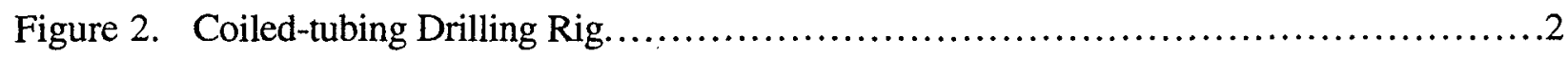

Figure 3. Coiled-tubing Unit on Drop Deck Trailer.....................................4

Figure 4. Coiled-tubing Reel Assembly (Stewart \& Stevenson) ...........................4

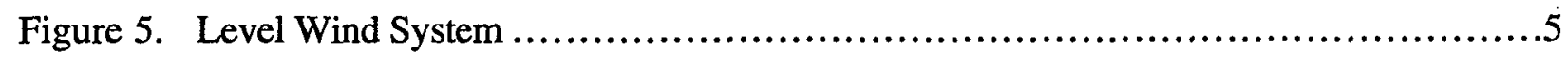

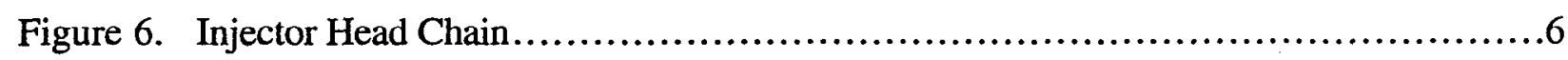

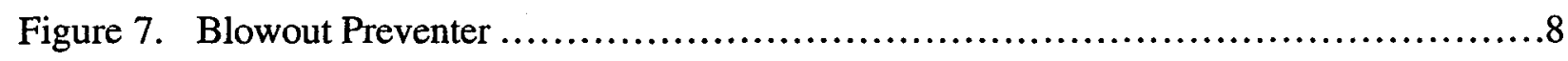

Figure 8. Hose Reel and Hose Assembly ......................................... 10

Figure 9. Crane Suspending Injector Over Wellhead ................................... 10

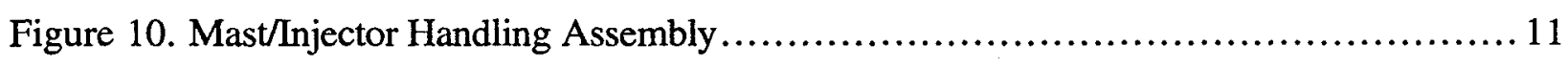

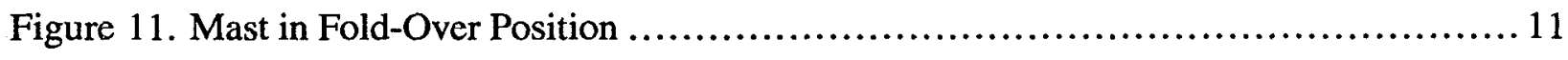

Figure 12. Tri-Flow Mud Cleaning Unit (Containerized) ............................... 12

Figure 13. Cutaway of Tri-Flow Mud Degasser....................................... 13

Figure 14. Trans-Foam Surface Equipment (Courtesy ECD Northwest)..................... 15

Figure 15. High-Pressure Compressor (Courtesy ECD Northwest) $\ldots \ldots \ldots \ldots \ldots \ldots \ldots \ldots \ldots \ldots$

Figure 16. RDDS Bottom-Hole Assembly ......................................... 16

Figure 17. Viper Measurement Points .............................................. 17

Figure 18. Coiled-Tubing Drilling Job in France....................................... 18

Figure 19. Typical Coiled-tubing Drilling Footprint. ..................................... 19

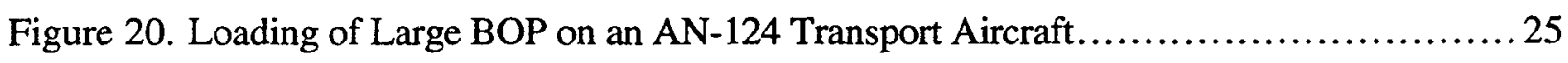

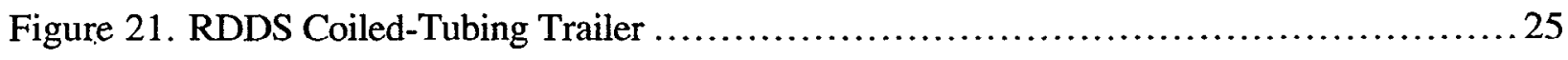

Figure 22. Nevada Test Site (NTS) Rhyolite Core Cemented into Drilling Block..............28

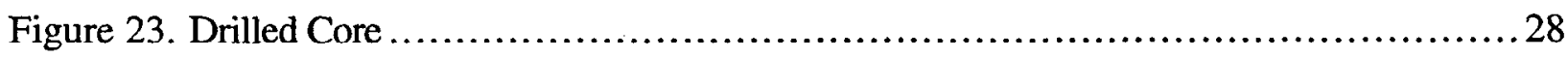

Figure 24. Penetration Rate in NTS Core .......................................... 29

Figure 25. Specific Energy vs. Weight-on-Bit for PDC Bit in NTS Core.....................29 


\section{LIST OF TABLES}

Page

Table 1. RDDS subsystems and major elements......................................

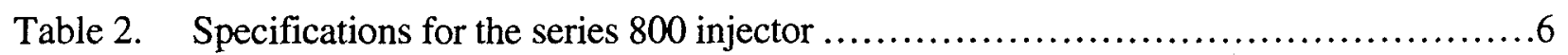

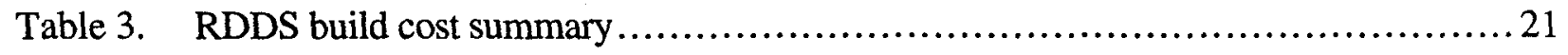

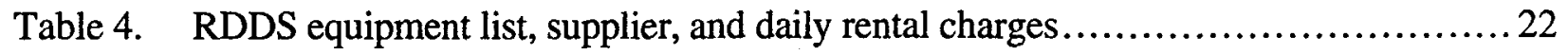

Table 5. Personnel required for a 24 -hour per day drilling project $\ldots \ldots \ldots \ldots \ldots \ldots \ldots \ldots \ldots \ldots . \ldots \ldots$

Table 6. Capacities of some possible cargo aircrafts to transport the RDDS .................24

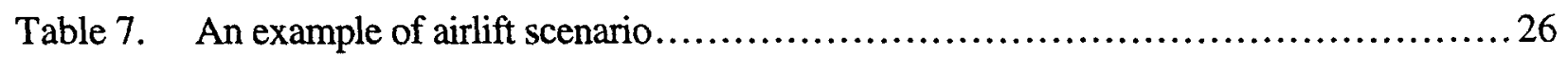




\section{INTRODUCTION}

\subsection{Background}

The Comprehensive Test Ban Treaty (CTBT) has been signed by many countries, including the United States. The U.S. Senate will start discussions of CTBT ratification in the near future. The Treaty aims to prevent any nuclear explosion from being conducted. A verification system is being implemented. It includes the possibility of On-Site Inspections (OSI) in a country where a suspicious seismic signal has been identified, which could come from a clandestine nuclear test.

As part of an OSI, the use of drilling is allowed by the CTBT so as to obtain irrefutable proof of a Treaty violation. Such proof could be in the form of diagnostics of very high gamma radiation levels and high temperatures underground, which could not be explained by a natural source.

A typical situation is shown in Figure 1, where the OSI team must find a nuclear cavity underground when only an approximate location is inferred. This calls for the ability to do directional drilling. Because there is no need for large borings and to minimize the cost and size of the equipment, slim-hole drilling is adequate. On that basis, an initial study by Lawrence Livermore National Laboratory [1] concluded that coiled-tubing (C-T) was the most attractive option for OSI drilling (Figure 2). Then, a preliminary design of a C-T Rapid Deployment Drilling System (RDDS) was performed by Maurer Engineering of Houston, TX [2]. Although a drilling mud system is also included in the RDDS definition, the preferred mode of operation of the RDDS would be drilling with air and foam. This minimizes water requirements in cases when water may be scarce at the OSI site. It makes the required equipment smaller than when a mud system is included. And it may increase the drilling rates, by eliminating the "chip hold-down" effect of a mud column.

Following this preliminary design study, it was determined that the preferred bottom-hole assembly for such a system would be the Viper system of Schlumberger Anadrill, with one essential modification from the version used in the oil-and-gas industry: the ability to record very high gamma levels. Under contract with LLNL, Anadrill modified the Viper gamma tool, a NaIbased probe, and verified that it provided reliable gamma data up to 64,000 cps, as opposed to the less than $200 \mathrm{cps}$ encountered in normal applications [3].

\subsection{Objectives of this study}

The objectives of this study, the second conducted by Maurer Engineering, were to:

- specify the RDDS components

- determine solutions for packaging and for deployment by aircrafts

- provide cost estimates for acquisition or lease of an RDDS, for transportation to the inspected country, and for operations at the site

- provide initial estimates of the rate-of-penetration of the RDDS in medium-strength rocks

The report is organized in two volumes, volume 2 containing the Appendices. 


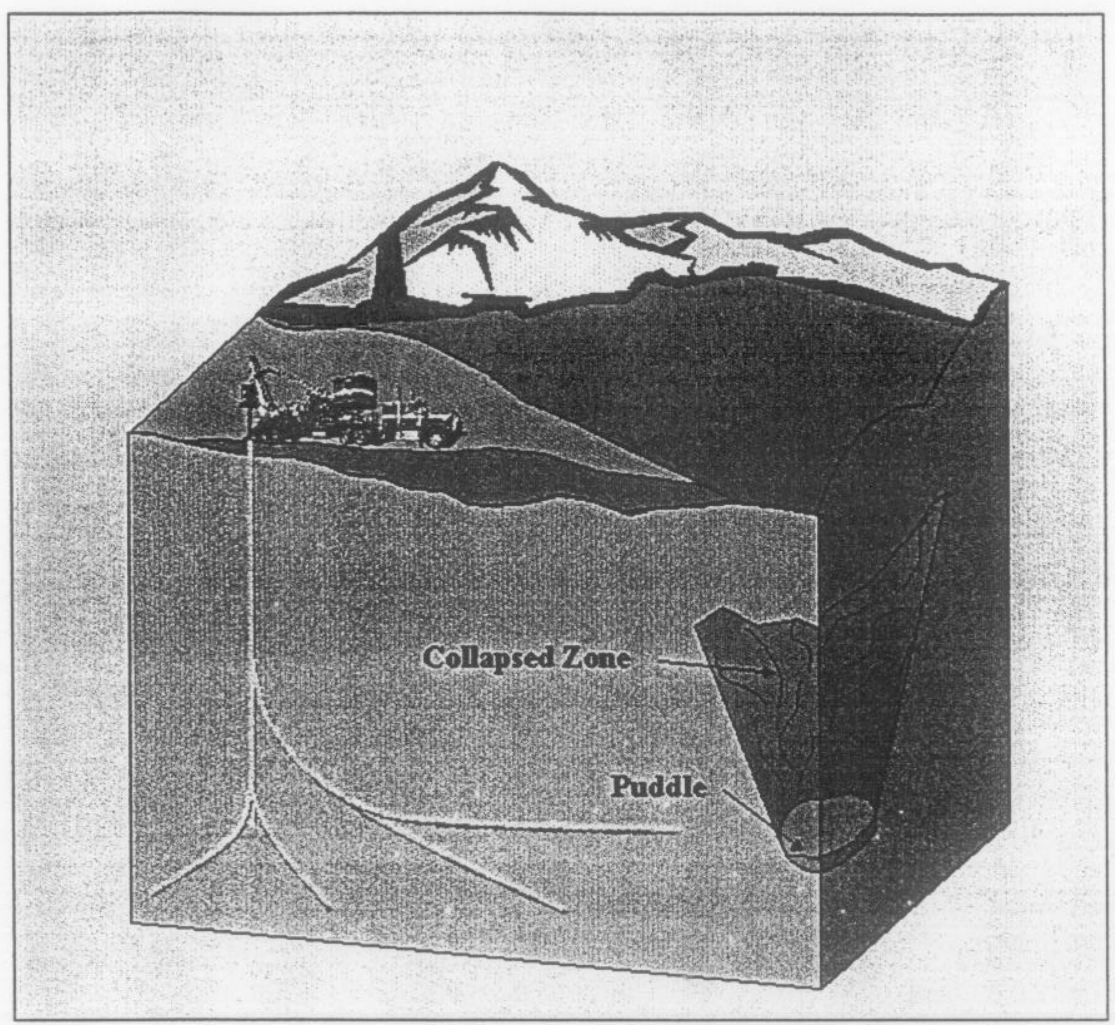

Figure 1: Typical RDDS drilling situation

\section{TUBING}

- INUECTOR

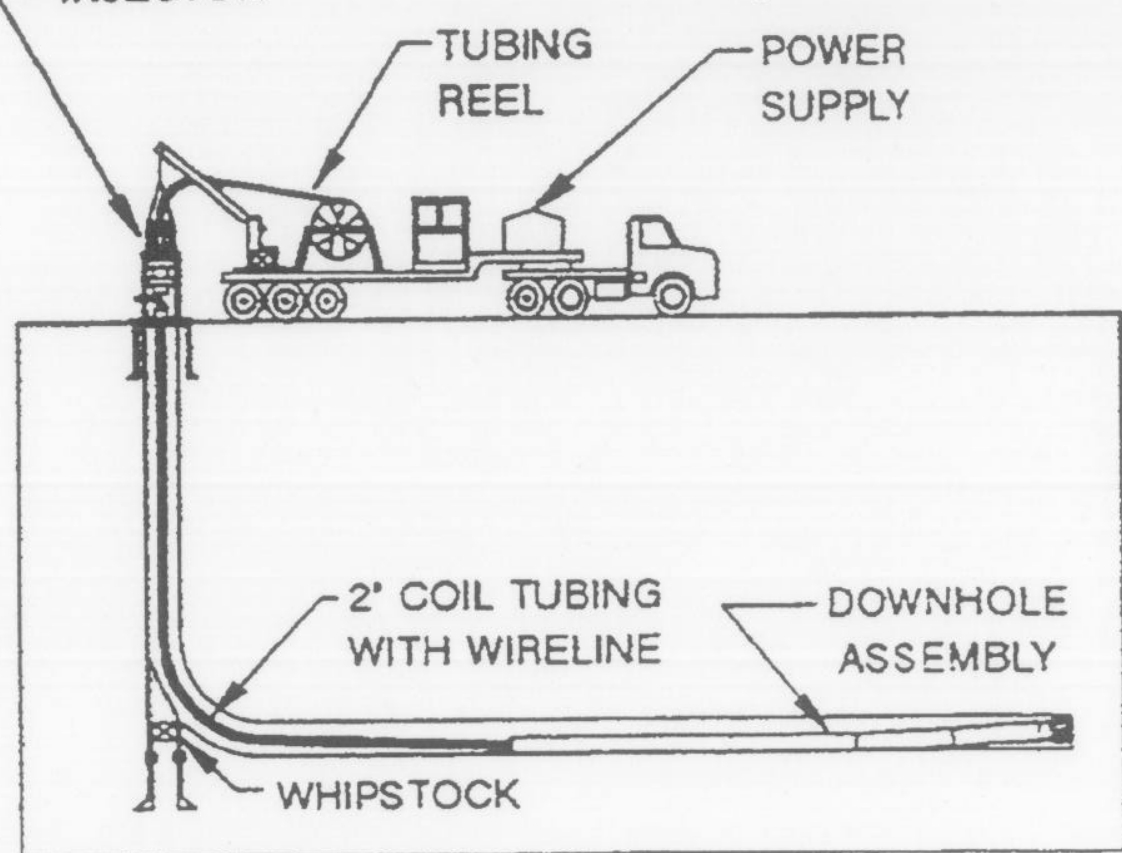

Figure 2: Coiled-tubing drilling rig 


\section{RDDS TECHNICAL DESCRIPTION}

This section provides a general description of the Rapid Deployment Drilling System. The RDDS is comprised of four majol subsystems which can be further subdivided into their major elements as shown in Table 1. Detailed technical and cost specifications of each subsystem are presented in Appendices A to D of the report.

Table 1. RDDS Subsystems and Major Elements

\begin{tabular}{|l|l|}
\hline \multicolumn{1}{|c|}{ Subsystems } & \multicolumn{1}{c|}{ Major Elements } \\
\hline Coiled-Tubing Unit & Coiled-tubing Reel Assembly \\
\cline { 2 - 2 } & Injector \\
\cline { 2 - 2 } & Control Cabin/Power Pack Assembly \\
\cline { 2 - 2 } & $\begin{array}{l}\text { Blowout Preventer (BOP) + Stripper } \\
\text { Assembly }\end{array}$ \\
\cline { 2 - 2 } & Hose Reel and Hose Assembly \\
\hline \multirow{2}{*}{ rrilling Mast/Injector Handling System } & Mast and Hoist \\
\cline { 2 - 2 } & Trailer Platform \\
\hline \multirow{2}{*}{ Drilling Fluid Handling System } & Water-Based Muds \\
\cline { 2 - 2 } & Air/Mist/Foam \\
\hline Bottom Hole Assembly (BHA) & Viper Instrumentation Package \\
\cline { 2 - 2 } & Mud Motors \\
\cline { 2 - 2 } & Drill Bits \\
\hline
\end{tabular}

\subsection{Coiled-Tubing Unit}

A coiled-tubing unit is proposed for the RDDS drilling system. This type of system uses continuous steel tubing stored on a spool, to act as the drill string. We recommend that the required functionality be provided in five modular packages. These are: 1) the coiled-tubing reel assembly; 2) injector; 3) control cabin/power pack; 4) hydraulic hose reel assembly and 5) blowout preventer and stripper seal assembly. This approach maximizes the range of airplanes and helicopters that can be used to transport the equipment to the field site, because each piece can be shipped separately or can be combined in various ways to satisfy air cargo dimensions and weight limitations. For example, Figure 3 shows the system mounted on a single drop deck trailer that measures 8.5 feet wide by 47 feet long. (Although it is well understood by the authors that the SI system of units is generally to be used, the English units were retained in this work because all the equipment discussed is specified in such units.) 


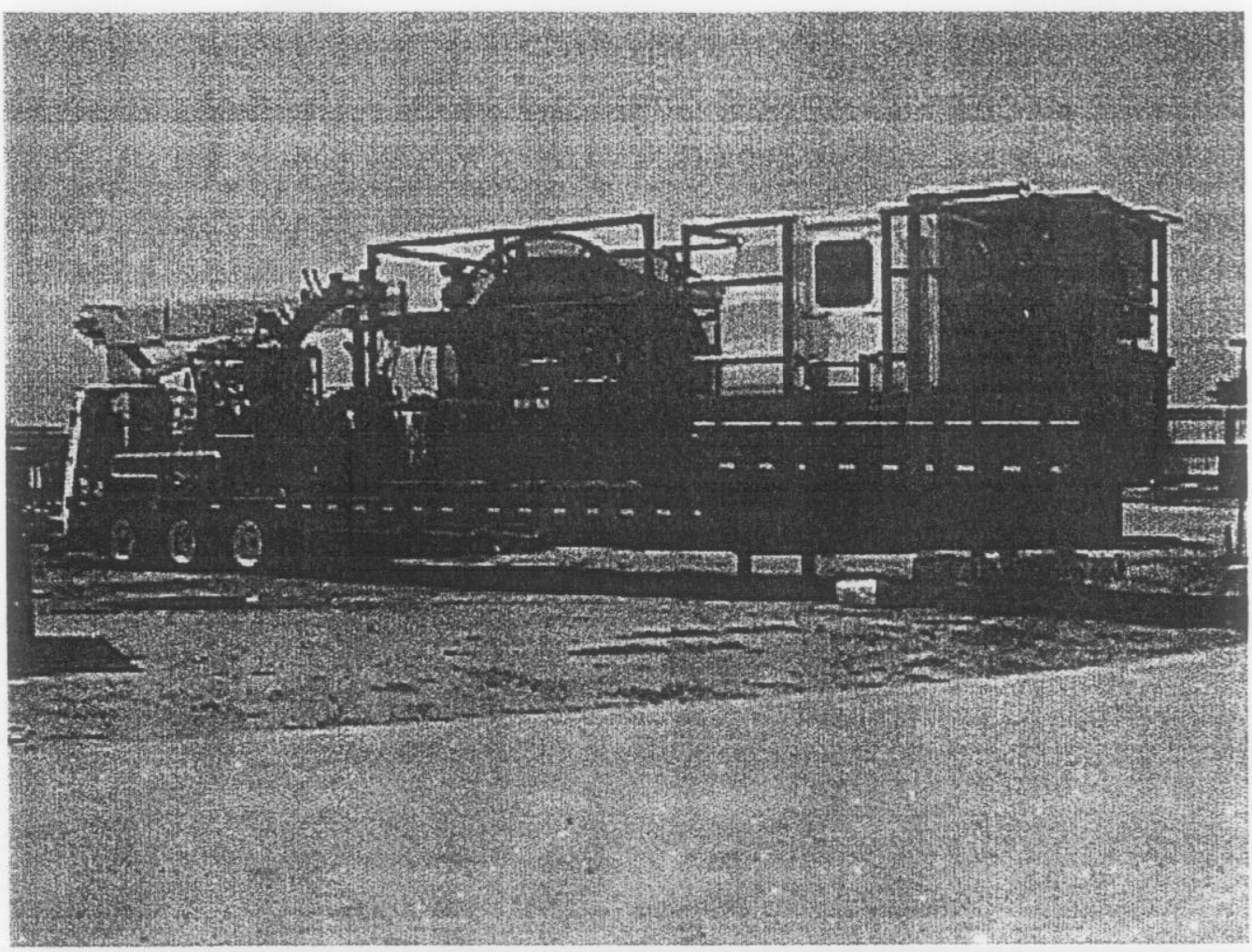

Figure 3: Coiled-tubing unit on drop deck trailer

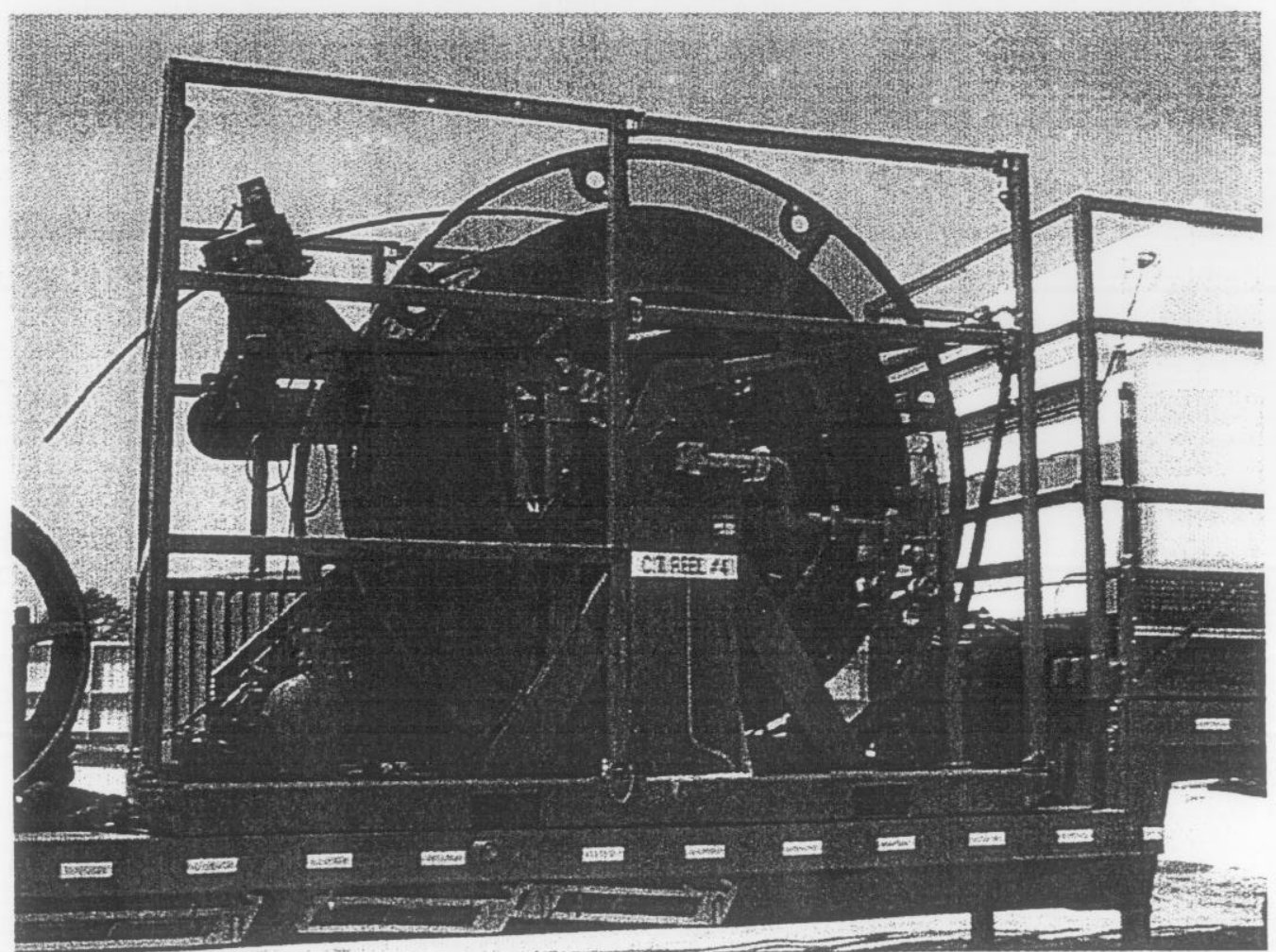

Figure 4: Coiled-tubing reel assembly (Stewart and Stevenson) 


\section{Coiled-Tubing Reel Assembly}

The coiled-tubing reel has a 90 inch diameter x 69 inch wide core and a 124 inch flange. This provides a capacity of approximately 5,250 feet of 2 inch OD x 0.156 inch wall QT- 800 grade steel tubing in six full layers. The reel has a 10 inch central shaft fitted with a 1-3/4 inch bore circulating swivel rated at 10,000 psi working pressure. The reel is driven by a geared radial piston hydraulic motor through a chain and sprocket drive assembly that operates at take-up speeds up to 200 feet per minute. Approximate loaded weight for the unitized reel assembly, similar to that shown in Figure 4, is 23,000 pounds (including the tubing).

A level wind mechanism (Figure 5) is installed on the reel assembly to maintain proper spooling of the tubing. The design consists of a diamond lead screw that is driven in synchronization with the drum rotation by a chain and sprocket and friction clutch arrangement powered by the reel's main drive shaft. A backup hydraulic motor is also connected to the diamond lead screw for manual override when required. Two hydraulic cylinders are used to raise and lower the level wind to match the desired pay off angle. A five digit, resettable mechanical depth meter is installed on the vertical slide section of the level wind.

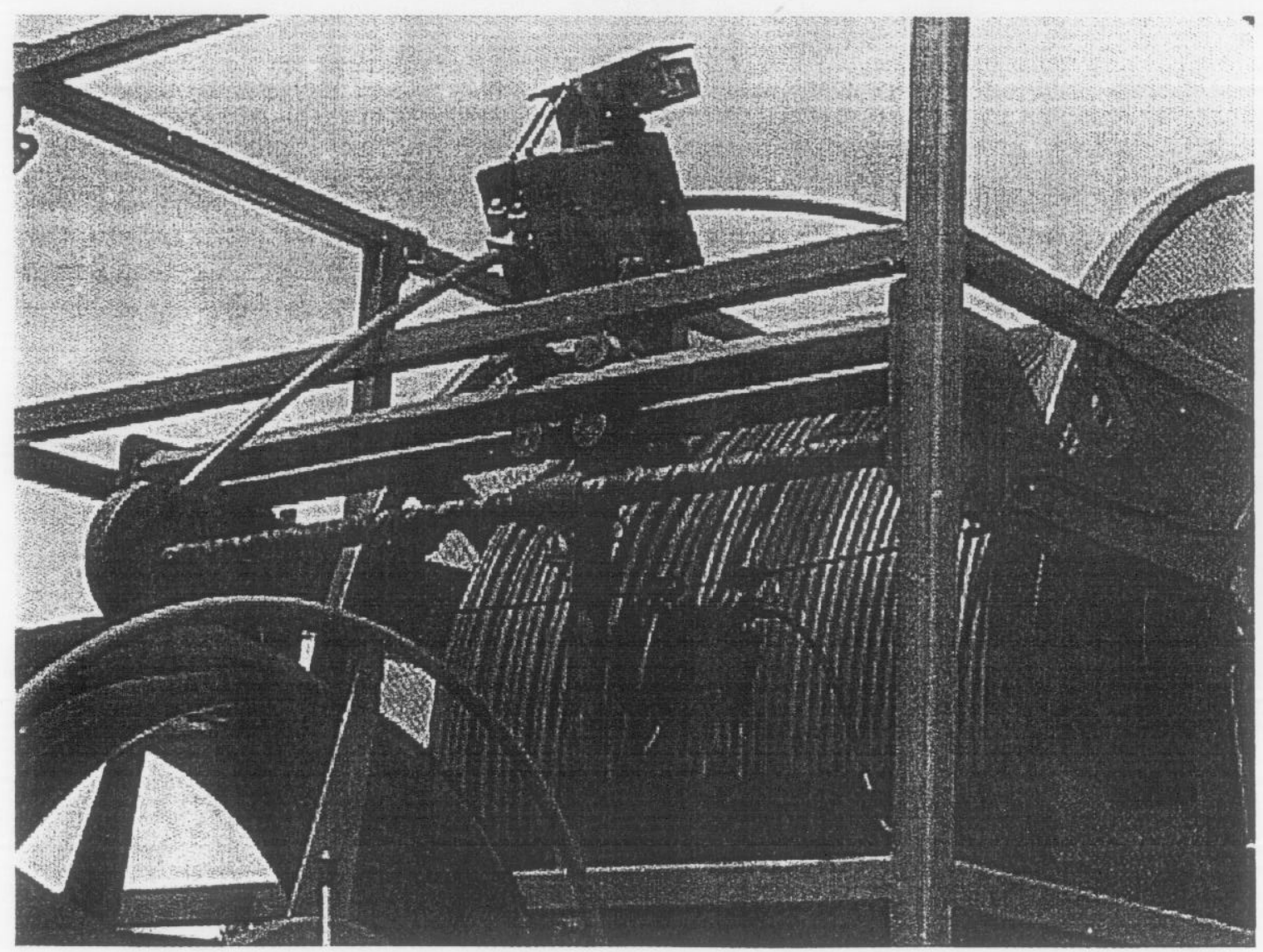

Figure 5: Level wind system 


\section{Series 800 Injector Head}

The injector head is used to move the coiled-tubing into and out of the well and, when necessary, to impart weight on the drilling bit through a process called snubbing. The injector uses specially formed chains to grip the coiled-tubing. The amount of gripping force ("squeeze") is controlled by hydraulic cylinders. Two variable-displacement motors drive the chain to provide the snubbing and lifting action of the injector. Table 2 gives the specifications for the series 800 injector.

Table 2. Specifications for the Injector

\begin{tabular}{|l|l|}
\hline Length: & 64 inches \\
\hline Width: & 49.5 inches \\
\hline Height: & 82 inches \\
\hline Weight: & 6500 lbs (including 72" gooseneck) \\
\hline Max. Pull Force: & 80,000 lbs \\
\hline Max. Speed: & Up to 200 feet per minute \\
\hline Chain Type: & Varia Block II with inserts for 2" C-T \\
\hline Drive Motors: & $\begin{array}{l}\text { 2 axial piston, variable displacement } \\
\text { hydraulic }\end{array}$ \\
\hline Gooseneck: & two-piece, flared \\
\hline
\end{tabular}

The injector's tubing block clearance when fully retracted allows for the passage of various tools normally used with the coiled-tubing string. For safety, velocity fuses are provided in the control circuit lines to prevent loss of control in the event of a hydraulic line failure. Fuse reset valves are provided for each circuit. Figure 6 shows the special injector chain.

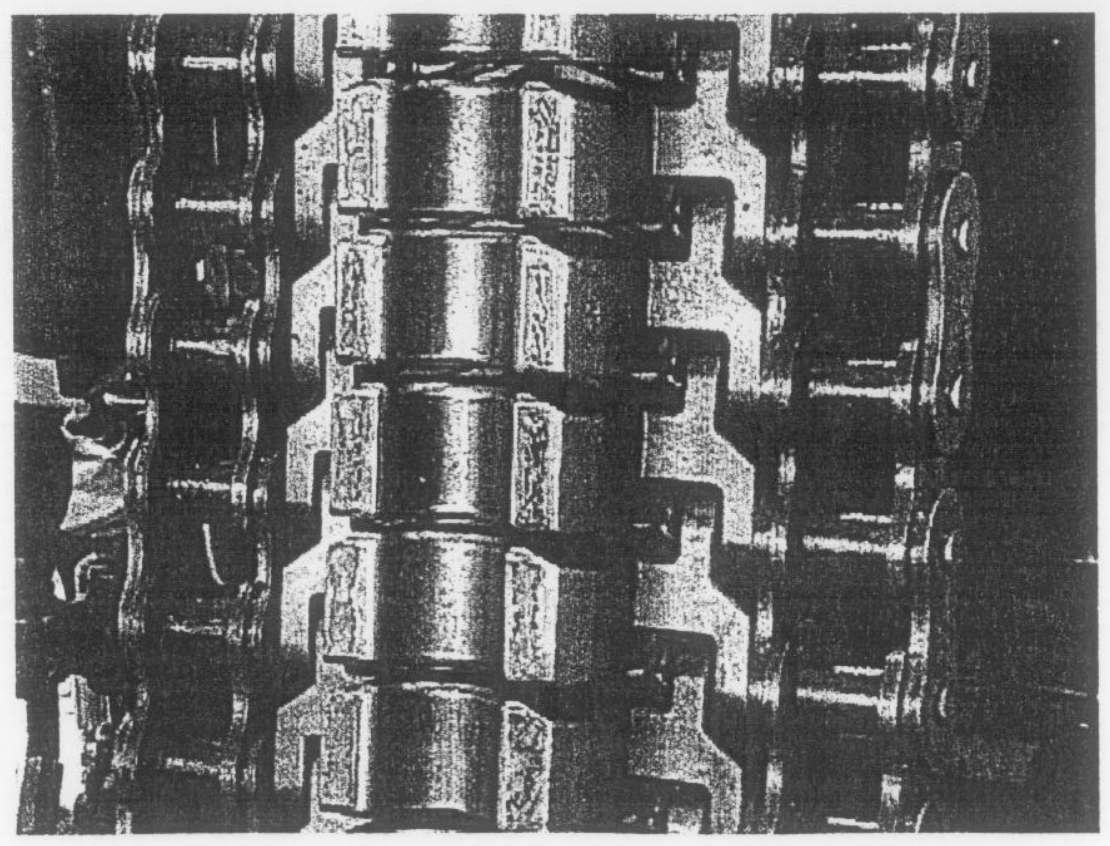

Figure 6: Injector head chain 


\section{Control Cabin/Power Pack Assembly}

The operator's control cabin and the coiled-tubing unit's power supply are integrated onto a single skid which measures 17 feet long $\times 8$ feet wide $\times 9.25$ feet high and weighs 15,000 pounds. The control cabin contains all the instrumentation and controls required to operate the coiled-tubing unit, while the power pack provides all the hydraulic, electrical, and pneumatic power needs. The control cabin interior is 7 feet wide $\mathrm{x} 10$ feet deep $\times 6.5$ feet tall and is constructed with a structural steel frame with aluminum walls. Standard equipment in the control cabin includes:

Engine Controls and Gauges:

- Engine Tachometer

- Air Operated Engine Throttle

- System Air Pressure Gauge

- Engine Stop Button (Fuel)

- Engine Emergency Kill (Air)

- Oil Pressure Gauge

- Water Temperature Gauge

Injector Controls:

- In/Out Selector Valve

- Speed Control Pressure Reducing

- Variable Speed Control

- Chain Traction Control

- Chain Traction Pressure/Run/Dump Selector Valve

- Chain Tension Control

- Injector Drive Pressure Gauge

Tubing Reel Controls:

- Tubing Reel Tension (Speed) Pressure Reducing Valve

- Tubing Reel Rotation Direction

- Tubing Reel Brake Control

- Level Wind Raise/Lower Control Valve

- Manual Level Wind Override Control Valve

- Inhibitor Control

Other Controls and Gauges:

- BOP Hydraulically Actuated Ram Control Valves

- BOP Safety Control Valve, Spring Return

- Stripper Packer Hydraulic Control Valve

- Stripper Packer Directional Control Valve

- Auxiliary Stripper Packer Directional Control Valve

- Stripper Selector Valve

- Auxiliary System Hydraulic Pressure Gauge

- Wellhead Pressure Gauge 
- Circulation Pressure Gauge

- Tubing Weight Indicator

- Backup Controls

An 8V-92TA turbocharged Detroit diesel motor rated at 475 brake horsepower at $2100 \mathrm{rpm}$ is used to run the main and auxiliary hydraulic systems, and the 12 CFM/120 PSI air compressor and to provide electrical power. The main hydraulic system uses a bi-directional, axial piston, pressurecompensated closed loop pump to run the injector. The auxiliary hydraulic system employs a tandem axial piston hydraulic pump to operate the tubing reel hydraulic motor, level wind raise/drop hydraulic cylinders, BOP rams, stripper/packer, injector chain tension and traction settings and other ancillary functions. The engine is provided with full switch gauge protection.

\section{Blowout Preventer (BOP) and Stripper Assembly}

In conventional oil and gas drilling, the BOP/stripper assembly is used to control well pressures and to allow entry and exit of tools from the well head under pressurized conditions. On the RDDS, it will help control drilling fluids and keep radioactive contamination within the mud system if the drill bit approaches the blast cavity. Exact procedures for preventing the escape of radioactive contaminants and warning devices are beyond the scope of this report. However, the community involved in past nuclear tests has extensive expertise in the nuclear safety of such drilling, and appropriate safeguards will be implemented for the RDDS.

The specific models recommended are the Stewart \& Stevenson type "CTQ" QUAD, 4-1/16 inch bore size, solid block blowout preventer (Figure 7) rated at 10,000 psi working pressure, and the 4-1/16 inch side door stripper assembly. The QUAD BOP and the side door stripper assembly weigh 6,100 and $1,450 \mathrm{lbs}$ respectively.

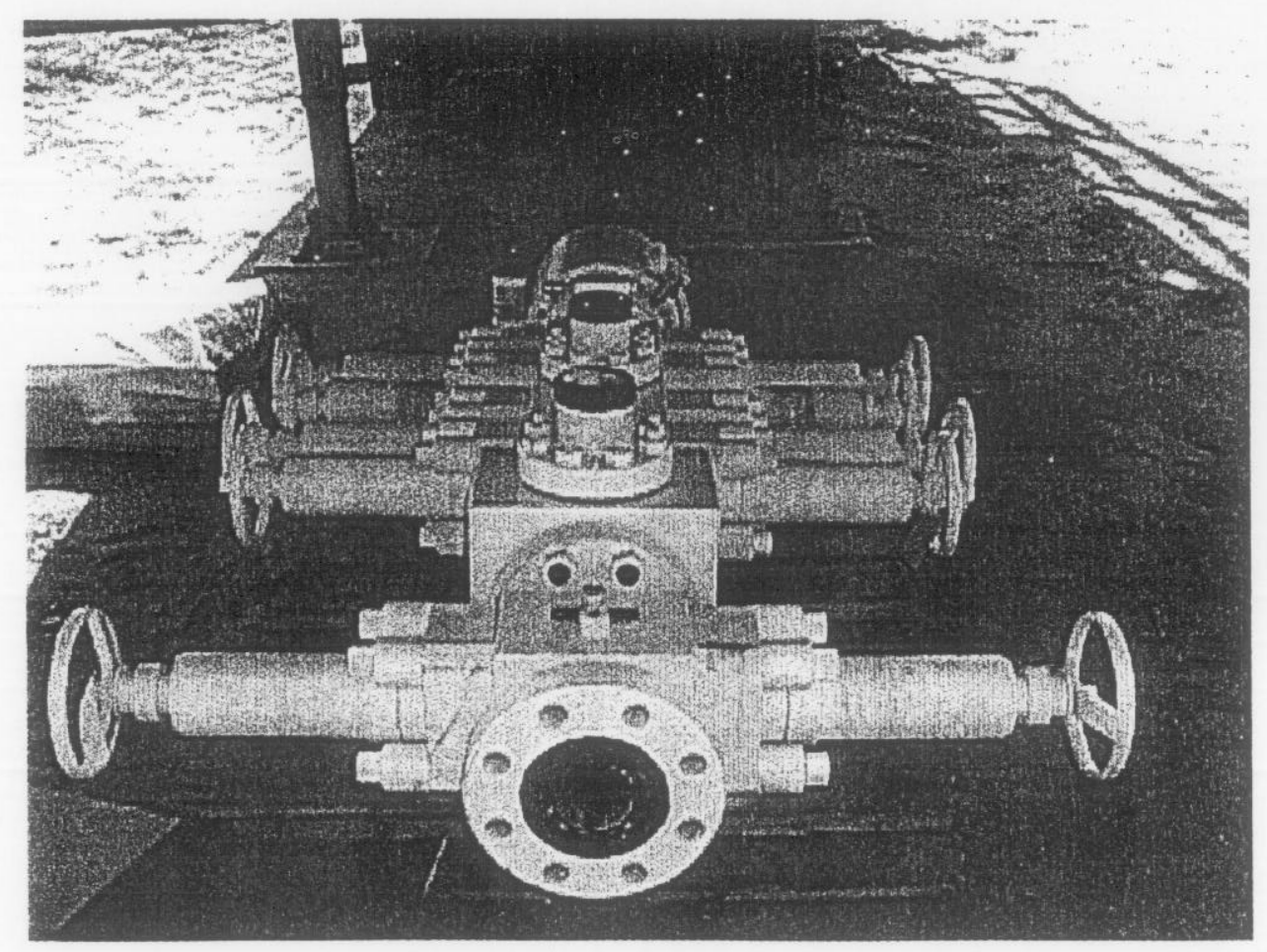

Figure 7: Blow-out preventer 


\section{Hose Reel and Hose Assembly}

This system provides the link between the control console/ power package and the working elements of the rig, such as the injector and blowout preventer. Hoses provide hydraulic fluid to power components and connect transducers to gauges on the console. Figure 8 shows a typical hose reel and hose assembly.

\subsection{Drilling Mast/Injector Handling System.}

Coiled-tubing systems are generally used for well clean out and well deepening operations where a well head and surface casing are already installed. In these situations, a crane can be used to suspend the injector over the well head as shown in Figure 9. However, in the case of the RDDS application, there is no existing well. The coiled-tubing unit will not only have to perform the drilling functions, it must also have the ability to spud the well and install casing. This necessitates use of a drilling mast and injector handling system.

The mast assembly is illustrated in Figures 10 and 11. It is a two piece, fold-over tower capable of handling single range tubulars up to 10-1/2 inches in diameter. The mast has 40 feet of travel and is equipped with a fingerboard to back rack doubles. The mast and associated cabling supports a maximum line pull of 35,000 pounds. A ladder is provided on one side of the mast for maintenance and fingerboard access. Two counterbalanced winch assemblies are installed on the unit for pipe handling and other lifting functions. Operation of the winches is hydraulic and powered off the coiled-tubing power pack.

The mast is designed to accommodate shipment either individually or as mounted on its heavy-duty trailer. The trailer work platform is equipped with a " $\mathrm{V}$ " door for stacking tubing in the pipe transport basket and a false rotary table having one manual slip assembly. Joint make and break out operations are accomplished using power tongs.

\subsection{Drilling Fluid Handling System}

Two different drilling fluid handling systems have been specified for the RDDS. The first system is for water-based muds while the second is to support drilling with air, mist or foam. The latter requires replacing the triplex mud pump with an air compressor. It is expected that sufficient geological information will be available for a given inspection site to make a determination of what elements should be mobilized.

\section{Water-Based Muds}

The recommended RDDS drilling fluid handling system is designed to be transported to the site inside a single $40 \mathrm{ft}$. container. It may also be shipped as individual components if necessary. The container has a roll top which can be opened to expose a self-contained jib crane and lighted work area as shown in Figure 12. Key elements of the system are described below. Detailed specifications are given in Appendix B.

Mud Tank - Drilling fluids will be mixed and stored in an 80-barrel capacity steel tank measuring 24'-6" long x 6'-8" wide x 3'-4" tall. The tank will be fitted with a 4-inch, high shear, low pressure mud mixing hopper, TFI Model 50 mud agitator, and three mud guns. 


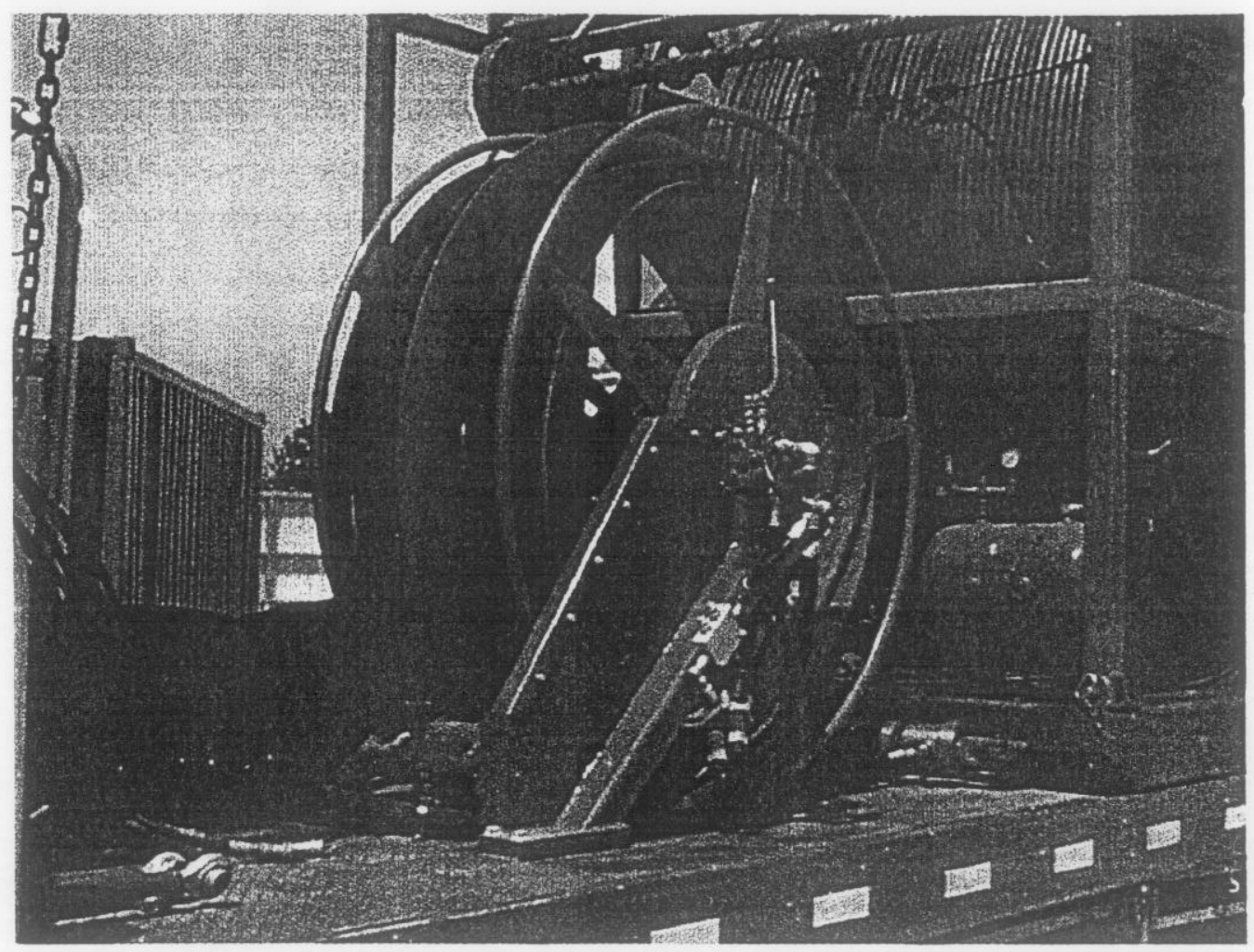

Figure 8: Hose reel and hose assembly

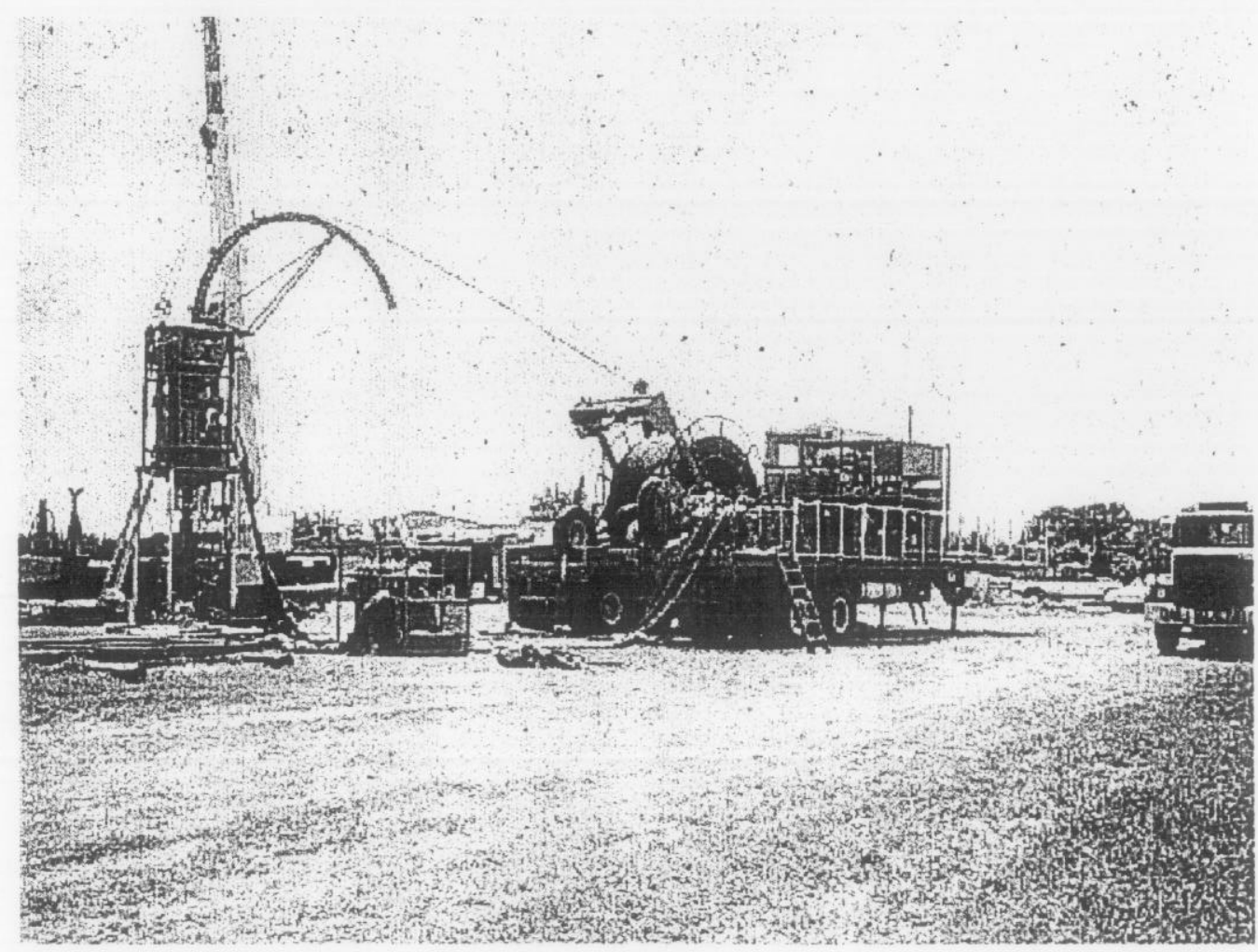

Figure 9: Crane suspending the injector over the wellhead 


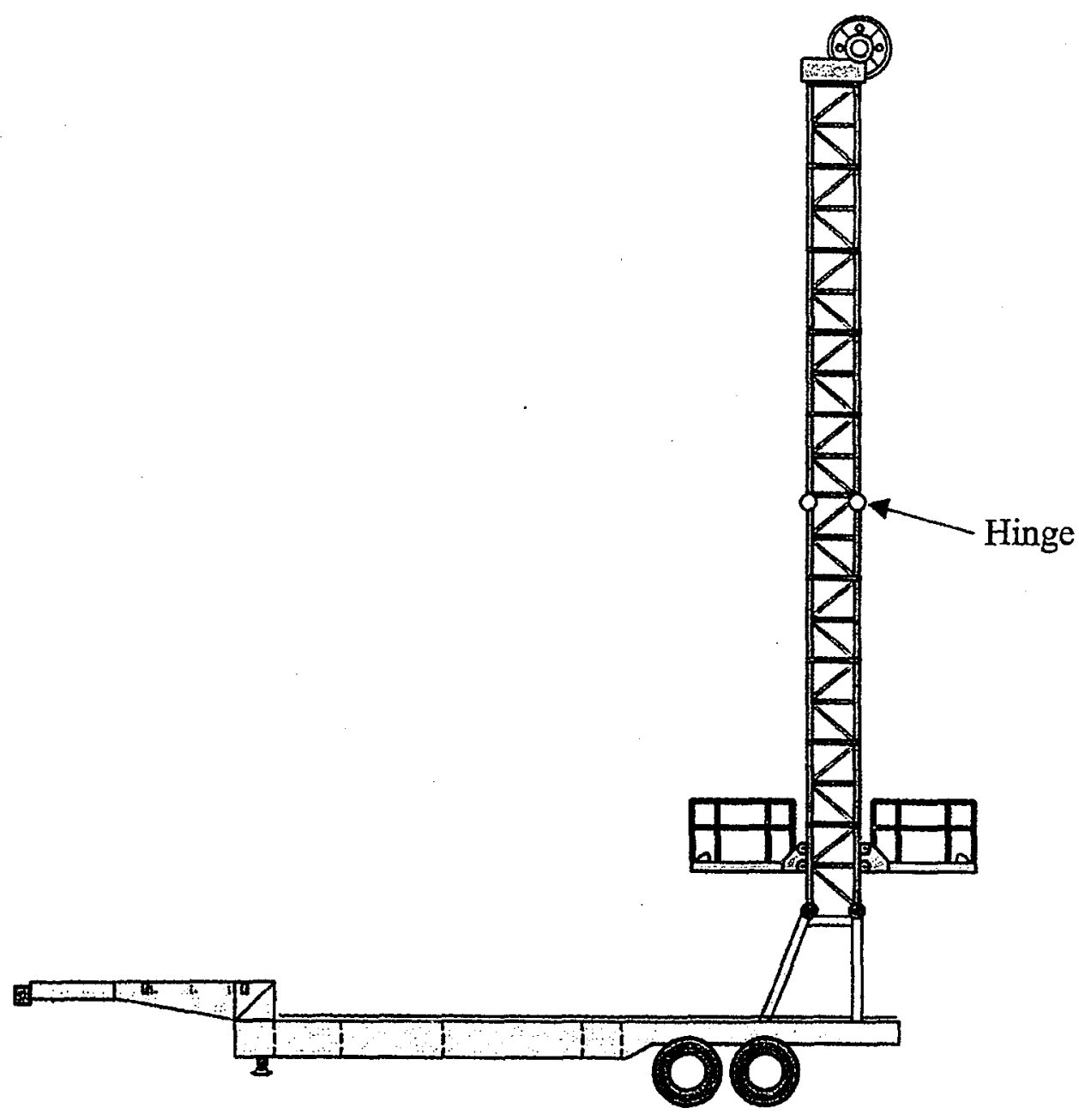

Figure 10: Mast/injector handling assembly (Stewart and Stevenson)

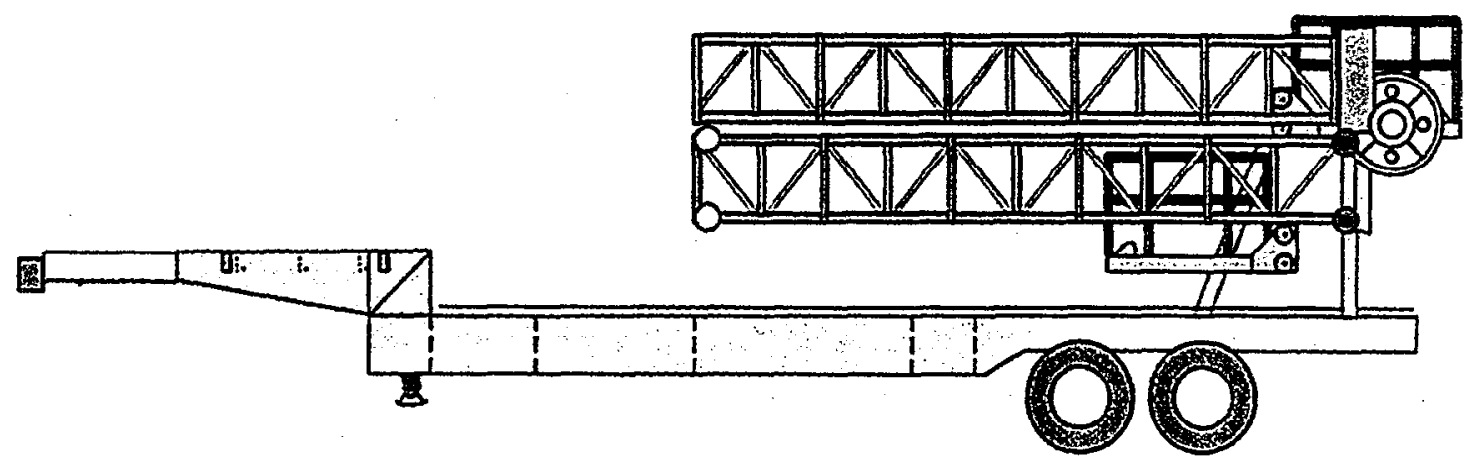

Figure 11: Mast in fold-over position (Stewart and Stevenson) 
JIB CRANE

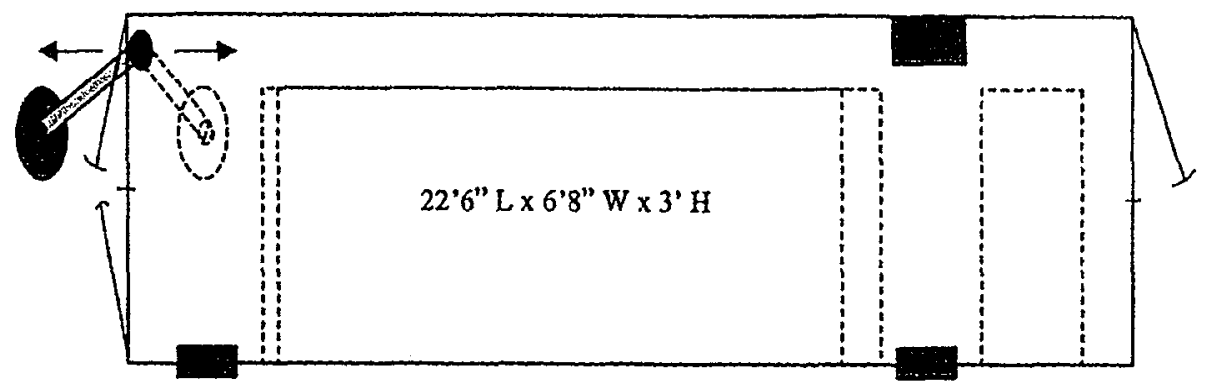

WALL FAN (2)

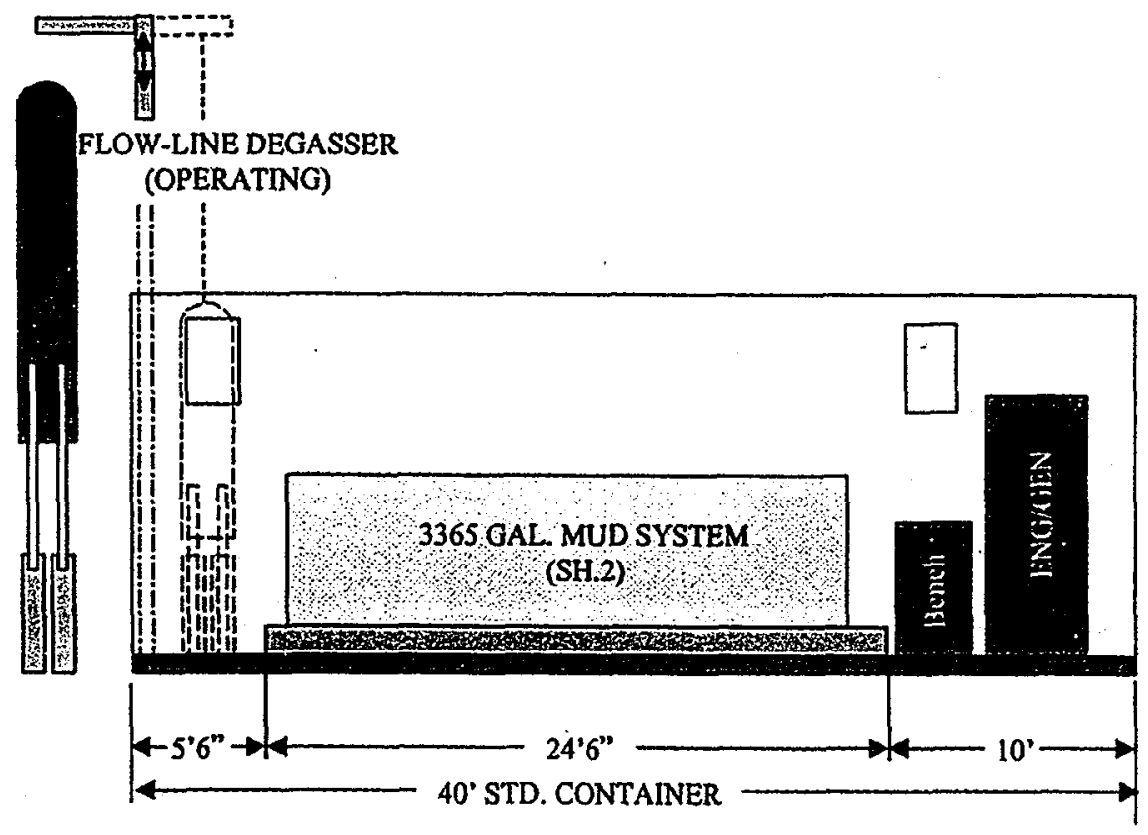

Figure 12: Tri-Flow containerized mud cleaning unit

Shale Shaker - A TFI-126, skid-mounted, single shale shaker with 300-gallon possum belly will remove fine cuttings from the mud. The unit weighs 1,420 pounds and is $7.75 \mathrm{ft}$. long $x 3.67 \mathrm{ft}$. wide $\mathrm{x} 3.5 \mathrm{ft}$. high. It is provided with 40- and 60-mesh screens in support of motor drilling.

Mud Cleaner- A skid mounted fluid separator having a 6-inch feed manifold and four, 4-inch polyurethane sand cones operates in conjunction with the shale shaker. The specified model is a TFI 4-126.

Flow-Line Degasser - In a typical oil-and-gas operation, this unit allows removal of well gasses before the mud reaches the shale shaker and mud tank. Mud returns entering the degasser are directed onto an impeller rotating at high speed. This impeller then throws the mud upward and over a series of baffles, exposing the mud in extremely thin sheets to below-atmospheric pressures generated by a high volume vacuum exhaust fan. The low pressure allows the gas to escape the liquid and be vented to the atmosphere (see Figure 13). The vertical vessel is 7 feet tall with a 24 inch diameter. As assembled, the fully configured unit has a weight of 2,600 pounds. 


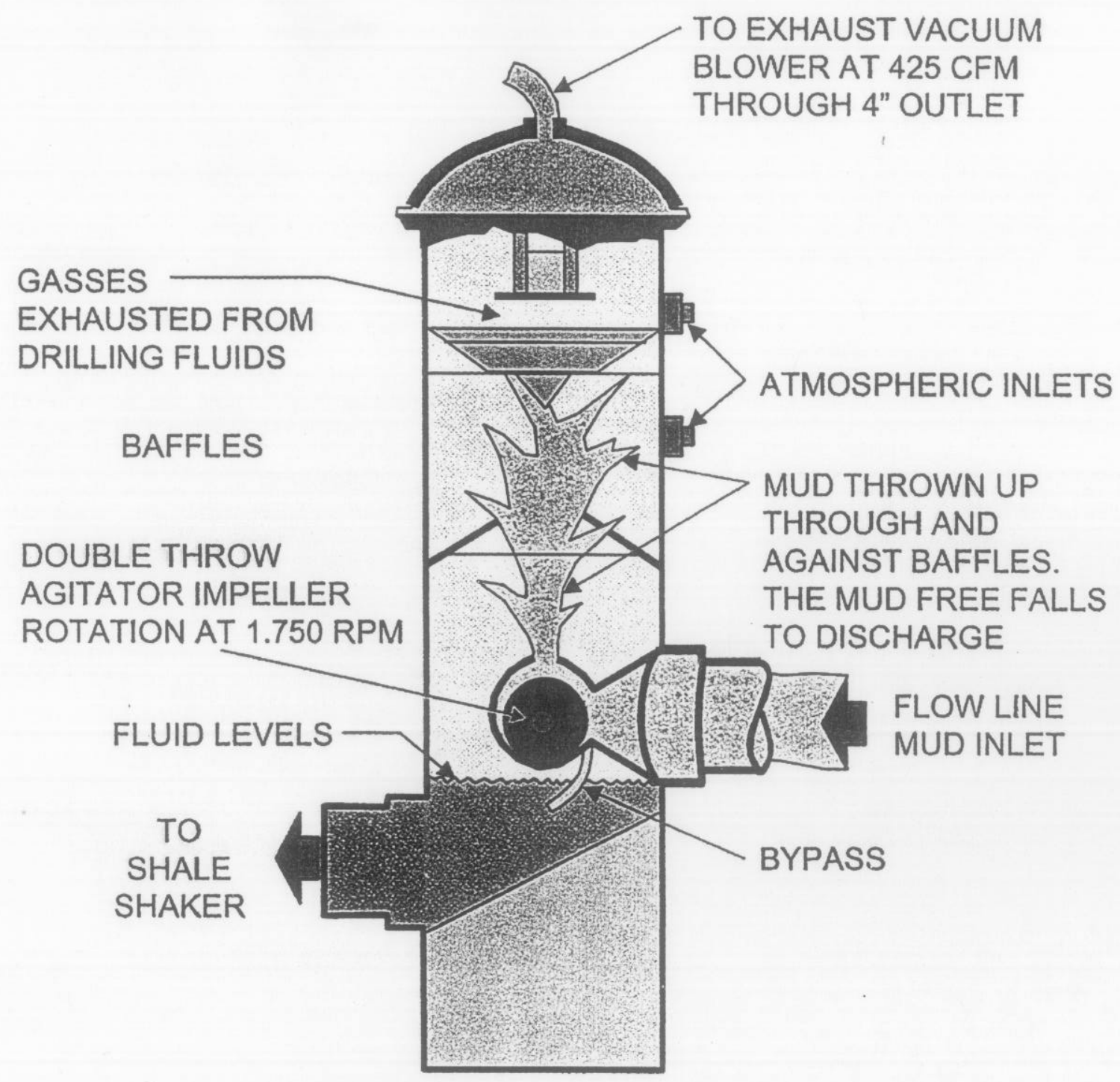

Figure 13. Cutaway of Tri-Flow Mud Degasser

For OSI's this system will be modified to eliminate the possibility of venting radioactive gases, based on the many years of experience in drilling "re-entry" holes in nuclear cavities.

Pit Pumps - Three pit pumps will be provided to support operation of the unit. The system will also include a 30-horsepower, centrifugal pump for charging the high-pressure pump.

Mud Cleaning Power Pack - The power to operate the shale shaker, agitators, pit and centrifugal pumps and the flow line degasser will be supplied by a $150-\mathrm{KW}$ generator driven by a 230 horsepower Perkins 1306-9TG1 diesel engine. The unit weighs 3,750 lbs. and measures 96 in. long x 42 in. wide x 56 in. tall. All electrical motors employed in the system have an explosionproof rating. 
High Pressure Pump - High pressure mud circulation will be accomplished using a SPM TWS 900 triplex pump equipped with 4-1/2 inch diameter plungers. This pump, when driven with a Detroit Diesel 12V-92TA connected to an Allison CLT-6061 transmission, is capable of providing a maximum flow rate of $545 \mathrm{gpm}$ and a maximum pressure of $10,000 \mathrm{psi}$. The high-pressure pump is not included as freight inside the $40 \mathrm{ft}$. container. Estimated skidded weight is $23,000 \mathrm{lbs}$ with dimensions of $16 \mathrm{ft}$. long $x 8 \mathrm{ft}$. wide $\times 8 \mathrm{ft}$. high.

\section{Air/Mist/Foam}

The difficulty of drilling hard rock has given rise to increased use of air, mist, and foam drilling. Air drilling employs only air, while mist drilling incorporates a small amount of water to improve motor and bit cooling or is the natural result of small amounts of formation fluid entering the wellbore. In foam drilling one adds a surfactant to the water. Foam is the most versatile of the three fluids. It has the best cuttings transport capacity and lowest annular velocity, and minimizes total air requirements. Foams must be broken up at the surface utilizing either specialized equipment and/or chemicals so they can be reused. This is especially important in the RDDS scenario.

In each case (air, mist, or foam), a compressible fluid is selected to increase the rate of penetration by reducing the hydrostatic fluid pressure that acts to hold cuttings down against the rock/bit interface. This type of drilling requires the addition of compressors, to provide high pressure air needed to lift cuttings from the bottom of the well to the surface and to operate the positive displacement motors. In addition, several components of the water-based mud cleaning system are needed in air, mist, and foam drilling. Specifically, these include:

- drilling fluid tank

- shale shaker

- power pack,

- mud degasser

- mud cleaning unit power pack

- triplex mud pump

Figure 14 is a schematic of a typical surface equipment setup for a trans-foam system. The acid and caustic chemical control system illustrated in the drawing is used to break the foam at the surface (using the acid) followed by restoring the desired $\mathrm{pH}$ level by caustic titration. The acid/caustic control system is not expected to be required for reasons cited in later paragraphs.

\section{High Pressure Air Compressors}

RDDS calculations for Moineau motor operation and proper cuttings removal for a typical range of depths and hole sizes conducted during the project yielded maximum air volumetric and pressure requirements of $1200 \mathrm{scfm}$ and $866 \mathrm{psi}$, respectively. These calculations are summarized in Appendix D. The unit shown in Figure 15 can satisfy the RDDS operating requirements. It consists of a Sullair 1150/350, two-stage air compressor and Ariel JGP/A booster. Motive power is provided by a Detroit Diesel 12V-92TA. The compressor is skid-mounted, with dimensions of $22 \mathrm{ft}$. long $\times 8.5 \mathrm{ft}$. wide $\times 8.5 \mathrm{ft}$. high, and weighs $31,420 \mathrm{lbs}$.

\section{Foam Breaking Equipment}

Judicious selection of the Tri-Flow mud degasser provides a secondary benefit in that its design has been shown capable of breaking most foams according to discussions with the manufacturer. This eliminates the need to transport acid to the job site to break the foam, and caustics to neutralize the $\mathrm{pH}$ after the foam has been broken. 


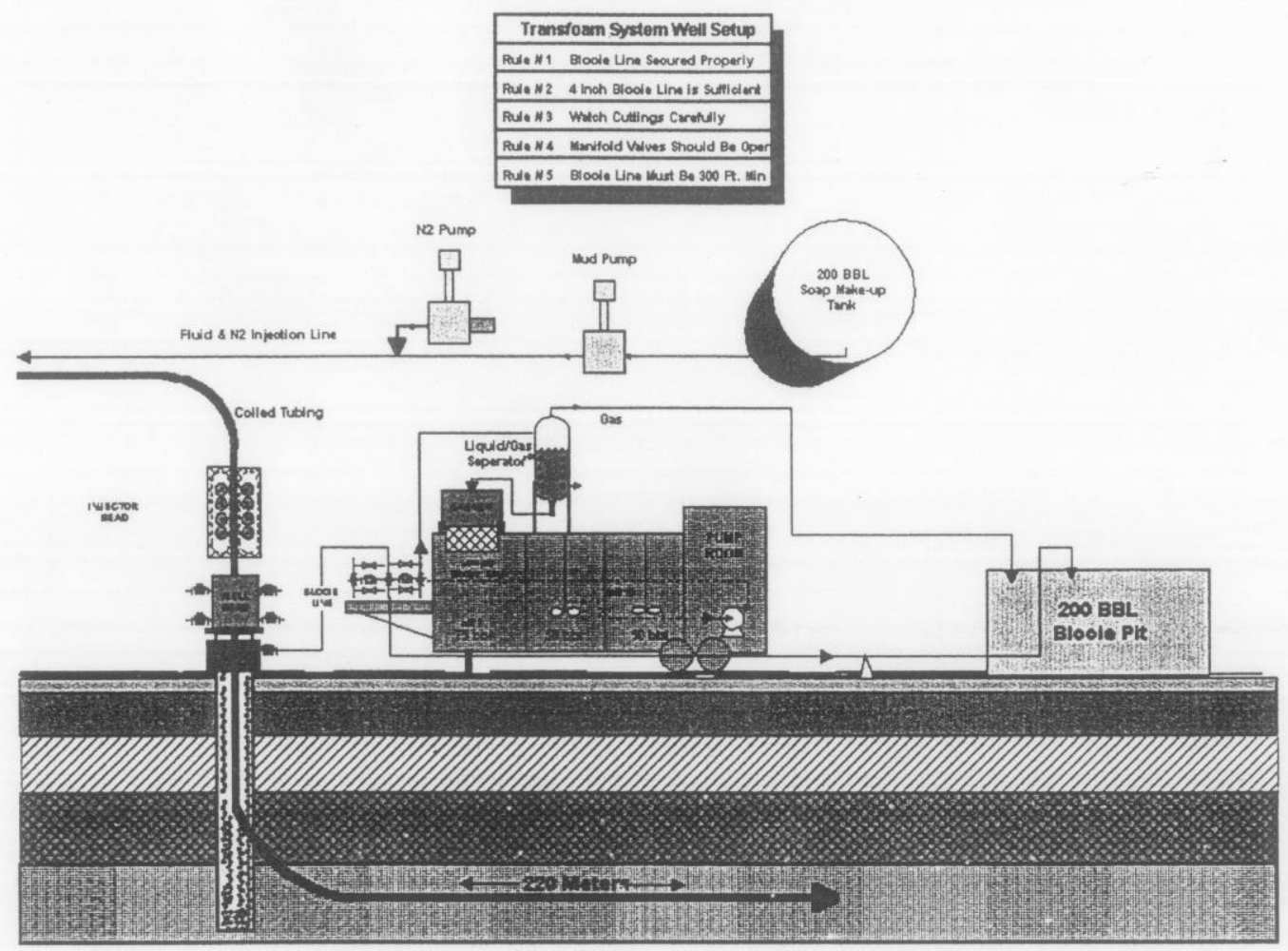

Figure 14. Trans-Foam Surface Equipment (Courtesy ECD Northwest)

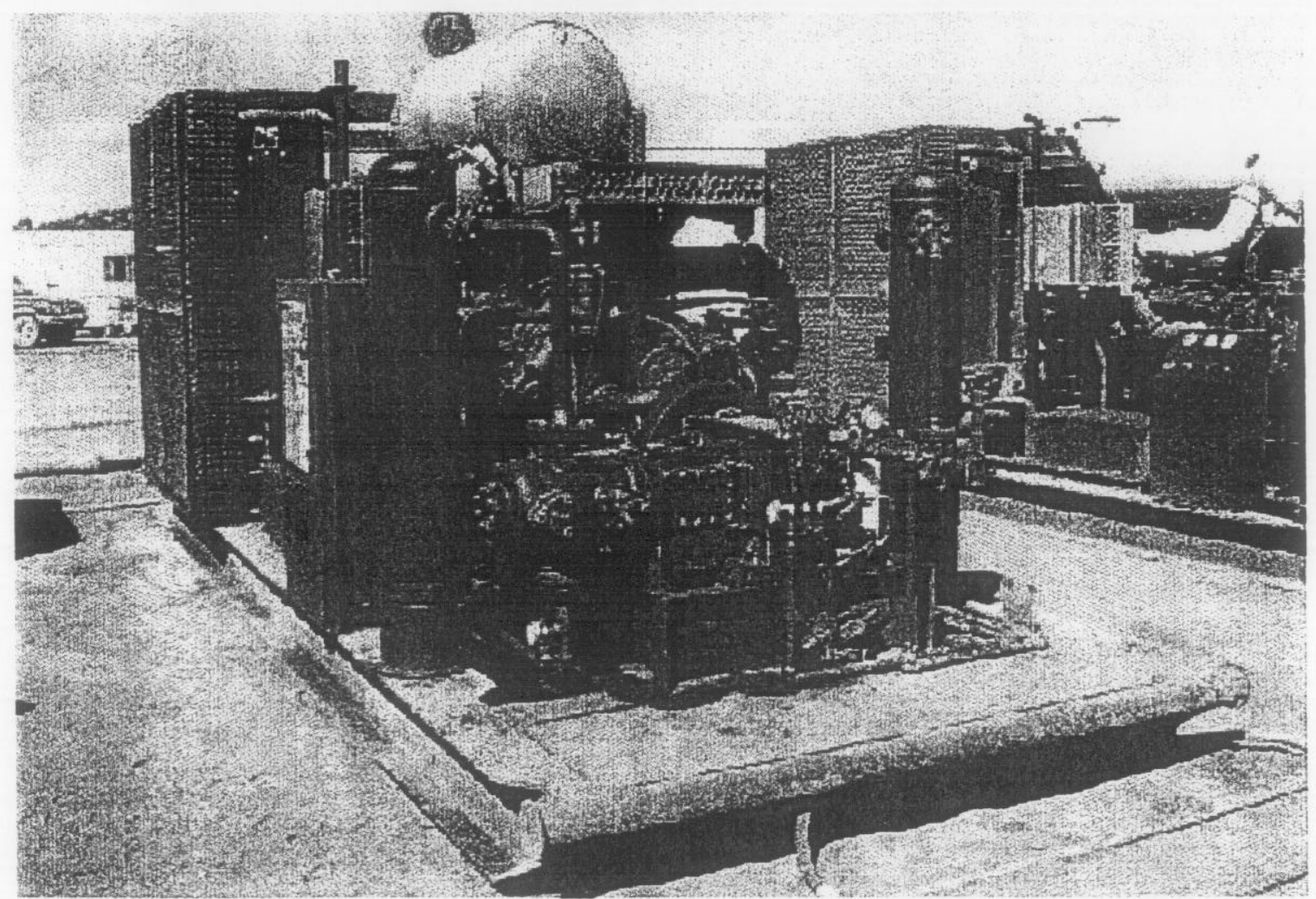

Figure 15. High-Pressure Compressor (Courtesy ECD Northwest) 


\subsection{Bottom Hole Assembly (BHA)}

The coiled-tubing BHA consists of: 1) a mud motor that provides the power for drilling by converting a portion of the hydraulic energy of the drilling fluid into mechanical energy (rpm and torque); 2) the wireline instrumentation package that tracks the borehole location and takes temperature and radiation readings; and the 3) steering assembly that turns the motor's bent sub in the desired heading. In conventional rigs, orientation of the motor is accomplished by rotating the drill string. Since coiled-tubing cannot be rotated, a DC electric motor is needed to align the mud motor's bend in the desired plane. For straight hole sections, the entire BHA is rotated continuously at $1 \mathrm{rpm}$ using a small DC motor in the orienting tool, thus canceling out the bent sub's tendency to build angle and change hole direction.

\section{Viper Instrumentation Package}

The instrumentation and motor orientation system for the RDDS unit will be provided by Schlumberger. The system, called Viper, consists of a down-hole instrumentation package and up-hole recording and monitoring package. It represents the latest generation of MWD tools for the coiled-tubing industry. The Viper employs tri-axial magnetometers and accelerometers to measure azimuth, inclination, and tool face, a thermal probe to measure temperature, and a sodium iodide detector to measure gamma ray radiation. Figure 16 shows the complete BHA with mud motor and Viper instrumentation/orientation system.

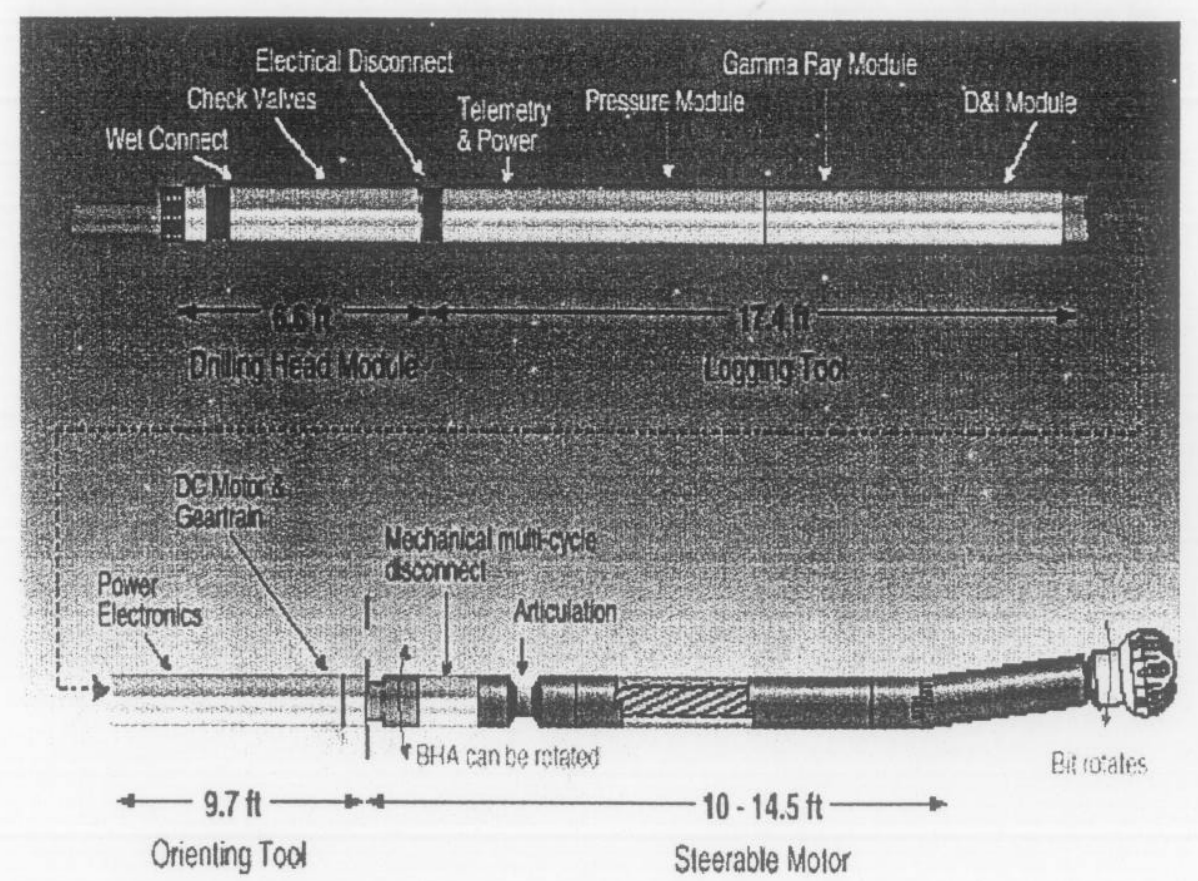

Figure 16: RDDS Viper bottom-hole assembly (Schlumberger-Anadrill)

The standard NaI gross gamma detector on the Viper is normally optimized to read 250 API units (approximately $125 \mathrm{cps}$ ). These are the typical low gamma readings seen in conventional oilfield drilling. To provide the irrefutable evidence of an event which cannot be explained from natural causes a credible diagnostic would be to show gamma radiation levels corresponding to at least $50,000 \mathrm{cps}$. Schlumberger has made the required modifications to the Viper and performed testing to demonstrate this expanded capability [3]. 
A critical concern for any MWD tool is the location of the measurement points for the various sensors. Figure 17 shows the approximate measurement points for the Viper tool.

The Viper requires minimal up-hole equipment. That equipment is used to read out and store the data collected by the sensors and to operate the DC-powered orientation motor. It will be located in the coiled-tubing control cabin, along with the other controls.

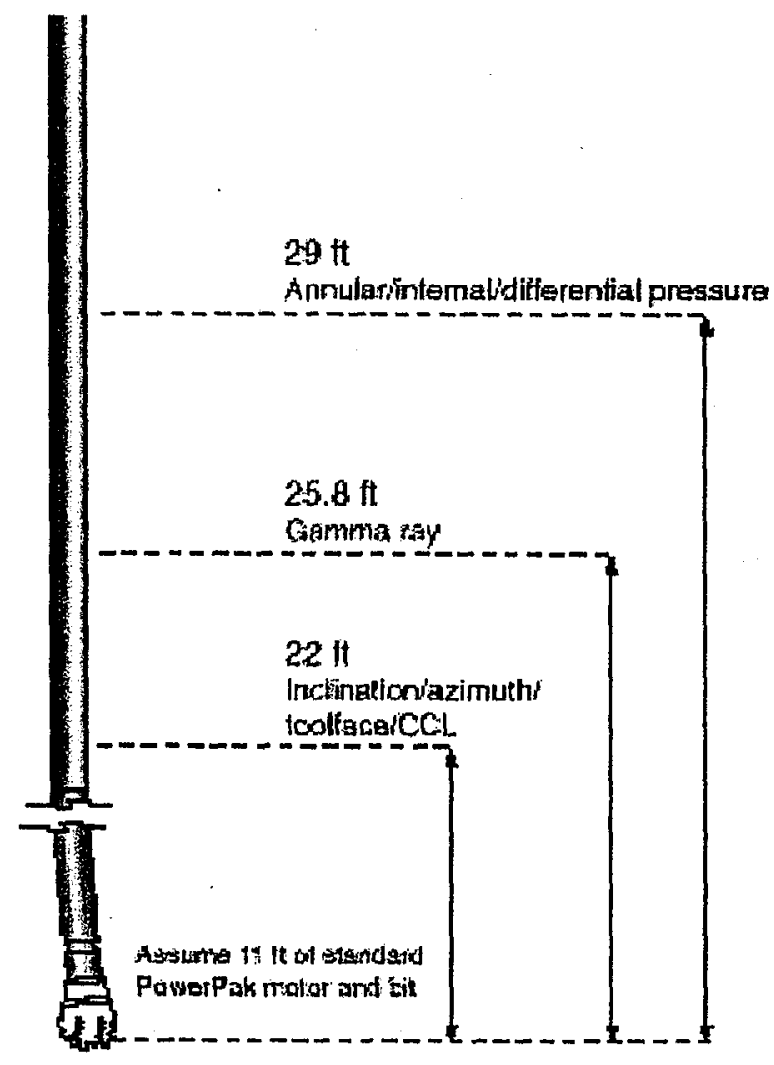

Figure 17. VIPER Measurement points

\section{Mud Motor}

The mud motor is an important element of the BHA, as it will supply the power to rotate the drill bit. The RDDS will use a 2-7/8 in. mud motor on 2-inch coiled-tubing. Several manufacturers offer this size of motor in both single and multi-lobe configurations. A multi-lobe motor with its high torque and low rotary speed, is the best choice for the type of drilling the RDDS is likely to perform (medium hard to hard rocks). Multi-lobe motors have speed and torque capabilities that can rotate either drag or roller bits. However, even multi-lobe motors run too fast for roller bits when operated on compressible drilling fluids. A typical 7:8 will turn $250 \mathrm{rpm}$ on water-based muds but almost $800 \mathrm{rpm}$ on air. If the formation cannot be drilled with a PDC bit, compressible drilling fluids will not be applicable.

Mud motor performance and reliability can be directly related to number of hours run. Motors that have been operated for a significant period are more subject to failure of the rubber stator. While a bearing pack can be rebuilt with new parts to reduce the chances of failure, rubber stator damage is cumulative. Considering the important nature of this drilling, it is advisable that new motors be used whenever this system if fielded. Failure to do so could slow drilling considerably due to motor failure. 


\section{Drill Bits}

It is difficult to predict the exact type of bit to use when the formation to be drilled is not known. The RDDS can use PDC or roller bits. If the formations are not too hard or abrasive, PDC bits will provide higher rates of penetration and longer life. These bits can also be used with compressible drilling fluids and are not damaged at faster rotary speeds. Roller bits are best for very hard formations. However, in this small size, the bearings in the cones are small and do not last long. Premium bits (sealed) in this size are available from only a limited number of manufacturers. If these bits are used, frequent trips to replace them will be required. It is better to replace a roller bit early than to let the condition deteriorate such that cones are lost in the hole. If this happens, then the hole must be side-tracked or a fishing trip must be made to recover the lost parts. Fishing trips can be quite costly. Testing needs to be conducted to determine the life of these roller bits and to produce valuable data that will save time if the equipment is ever used in a real field operations.

In an actual OSI, drilling would not start until a few weeks after the beginning of the inspection. This should provide enough time for performing basic rock tests at the site, which would guide the selection of the drilling bits [4].

\subsection{Footprint of the RDDS}

The RDDS has a smaller "footprint", or required location size, than a conventional rig and it provides a closed circulation system which reduces spills to the environment. Figure 18 is a picture of the first C-T drilling (CTD) job, done in France.

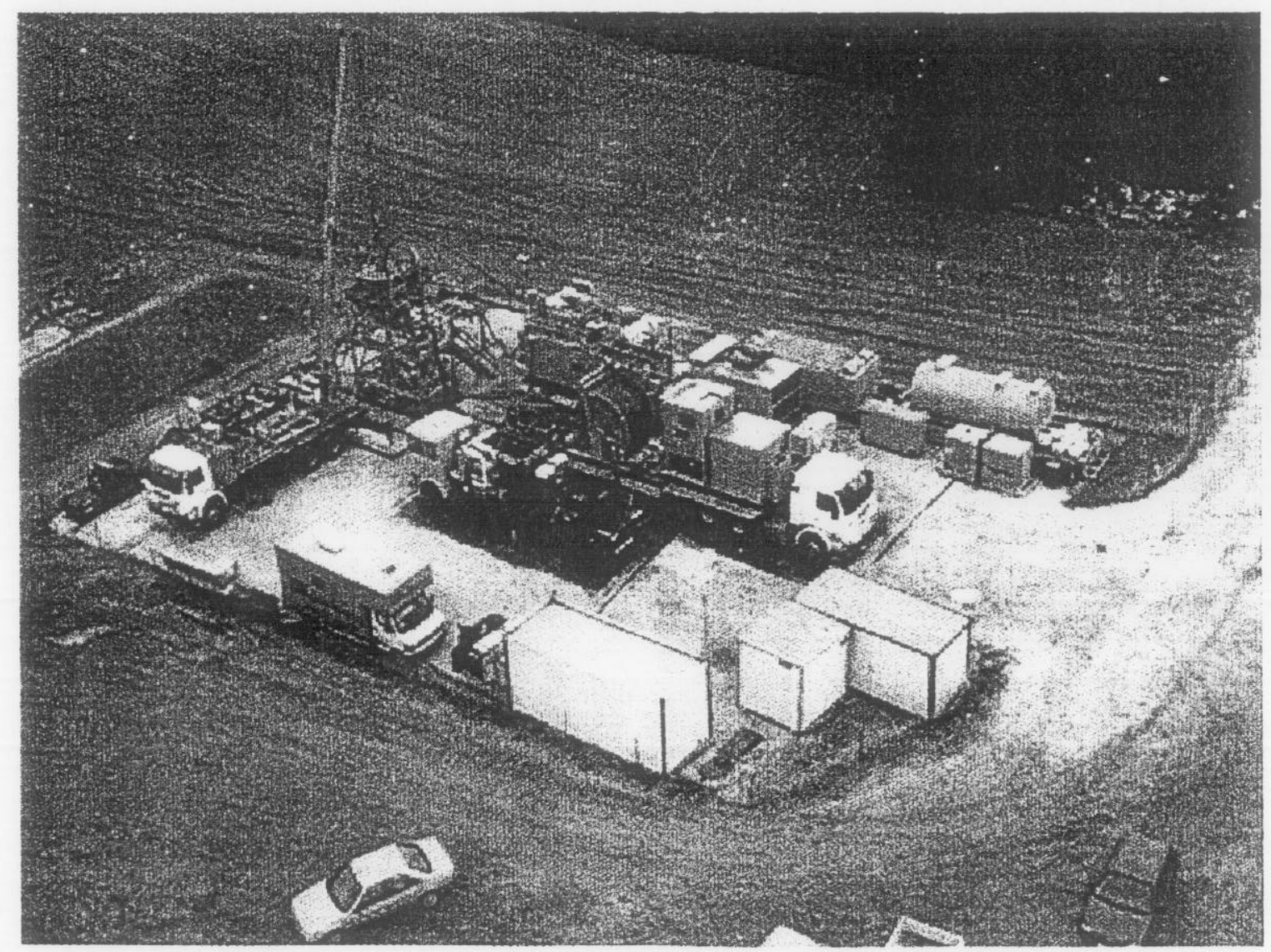

Figure 18: Coiled-tubing drilling job in France 
Figure 19 is a typical CTD location lay-out for a land-based project. The lay-out is approximately 36 by 12 meters. This can be reduced even further, if necessary.

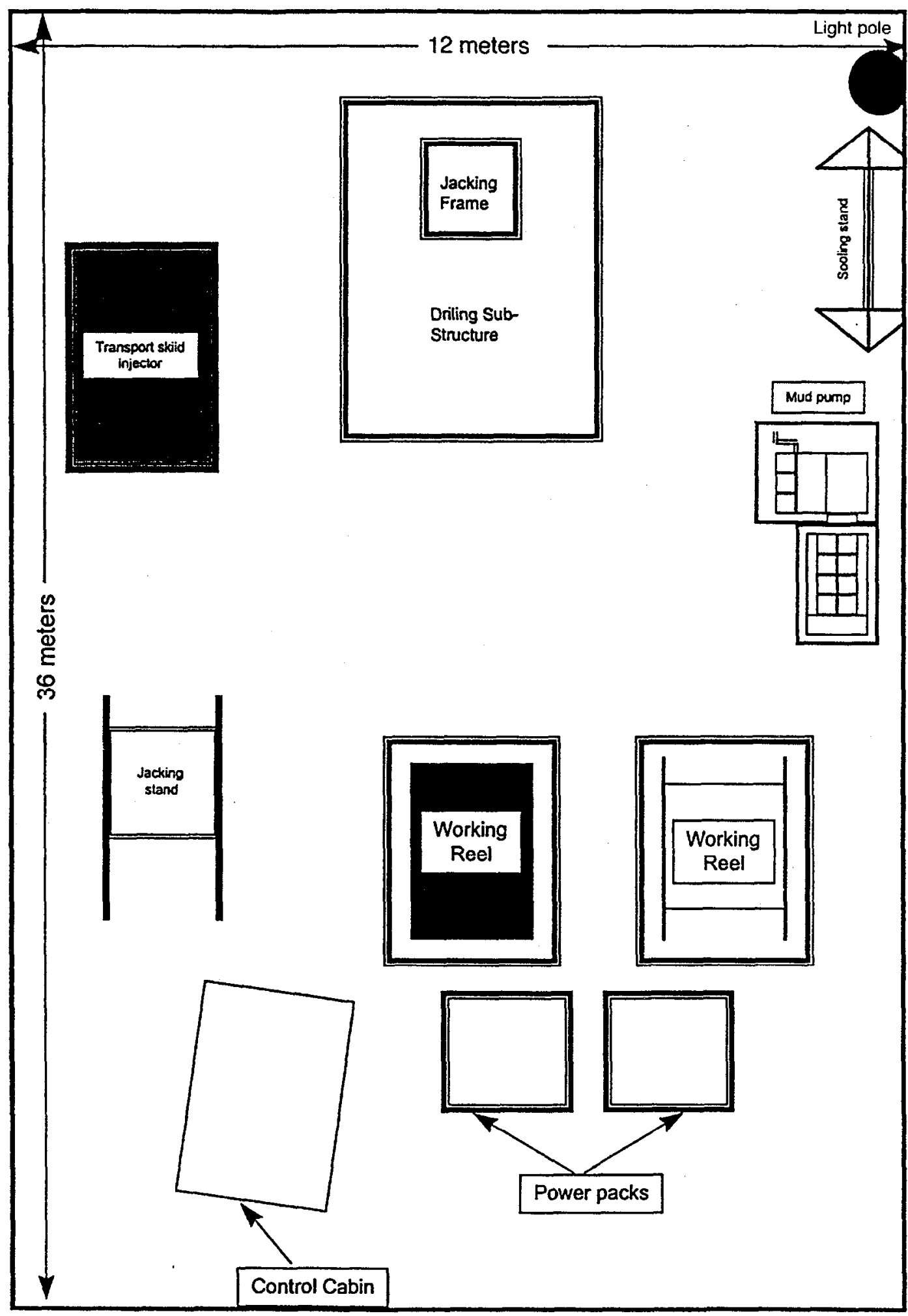

Figure 19 : Typical coiled-tubing drilling footprint 


\section{COSTS OF ACQUISITION AND OPERATION}

In order to have access to a proven drilling system, the CTBT Organization could buy such a capability and put it in storage. Accordingly, the cost of purchase of a C-T drilling system is provided. But, this equipment may be costly to maintain in good working order, and this option does not offer the possibility of taking advantage of new developments such as more efficient and lighter-weight systems.

The preferred option seems to be renting as much of the system as can be done on the time-scale of an OSI. Some of the items still may only be available for purchase. This would be determined if and when an actual OSI was called for. To establish a baseline, we are also providing rental costs for an operation, based on the Schlumberger-Dowell C-T drilling system which includes the Viper tool specified for the RDDS.

\subsection{Equipment Considerations}

The RDDS package must be capable of running casing and spudding the well, since there will be no existing well to work from. These factors require that the unit have a mast for running tubulars at the surface, such as the one described in section 2.2. It is also advisable to plan on deploying two C-T strings, so as to have a spare one. The second string would be on a "drop-in" drum reel, in order to reduce the overall weight.

The control cabin will be standard C-T equipment that allows room for the Viper surface acquisition and control computer. It will also contain controls for all equipment during the drilling process, including fluid pumps and BOP controls.

The unit must be self-contained and thereby will require items for all possible contingencies. Fishing tools will be required in the event that BHA components are lost in the hole while drilling. A comprehensive inventory of spare parts for the RDDS will also need to be included.

\subsection{Purchase Costs}

The estimated cost to build/purchase the RDDS unit specified in Section 2 is shown in Table 3. This cost does not include spare parts, consumables, and other ancillary equipment which may be desired. In addition, the quotation does not include the mechanical and electronic elements in the BHA. These would be rented immediately prior to mobilization of the RDDS in order to avoid maintenance and calibration issues that would otherwise arise with a package kept in storage, as well as to take maximum advantage of any technological improvements.

This estimate assumes using off-the-shelf components wherever possible to minimize nonrecurring engineering charges, and is based on information provided by the following companies:

- Stewart \& Stevenson Services, Inc., 10750 Telge Road, Houston, TX 77095

- Tri-Flow International, Inc., P.O. Box 2626, Conroe, TX 77305

- SPM Flow Control, Inc., 7601 Wyatt Drive, Fort Worth, TX 76108

- ECD Northwest, Inc., 2462 Industrial Blvd., Grand Junction, CO 81505 
Table 3. RDDS build/purchase cost summary

\begin{tabular}{|c|c|c|c|}
\hline ITEM & Description & Qty. & Price \\
\hline 1 & $\begin{array}{l}\text { Model TT-15080 Trailer Mounted Coiled-tubing } \\
\text { Unit }\end{array}$ & 1 & $\$ 737,163$ \\
\hline 2 & Trailerized Mast/Injector handling System & 1 & $\$ 343,000$ \\
\hline 3 & Unitization of Items 1 and 2 & 1 & $\$ 36,500$ \\
\hline 4 & Auxiliary Reel Stand & 1 & 8,406 \\
\hline 5 & High-Pressure Piping & 1 & $\$ 33,534$ \\
\hline 6 & Lubricator/Side-Door Stripper Assembly & 1 & $\$ 38,406$ \\
\hline 7 & Containerized Mud Tank/Jib Crane & 1 & $\$ 75,000$ \\
\hline 8 & TFI-126 Shale Shaker & 1 & 7,500 \\
\hline 9 & TFI-4-126 Mud Cleaner & 1 & $\$ \quad 16,750$ \\
\hline 10 & TFI Flow Line Degasser & 1 & $\$ \quad 19,950$ \\
\hline 11 & Pit Pumps & 3 & $\$ 19,500$ \\
\hline 12 & 30 HP Centrifugal Pump & 1 & 6,750 \\
\hline 13 & TFI 4" Mud Hopper & 1 & 2,095 \\
\hline 14 & TFI 5 HP Agitator & 1 & 6,250 \\
\hline 15 & TFI Mud Guns & 3 & 2,625 \\
\hline 16 & $150 \mathrm{KW}$ Power Plant & 1 & $\$ \quad 26,500$ \\
\hline 17. & SPM TWS Triplex Pump Unit & 1 & $\$ 266,884$ \\
\hline 18 & High Pressure Air Compressor & 1 & $\$ 393,500$ \\
\hline & TOTAL (U.S. Dollars) & & $\$ 2,040,313$ \\
\hline
\end{tabular}

\subsection{Rental Costs}

Table 4 gives the RDDS equipment list, suppliers, and daily rental charges for components of the drilling system. 
Table 4: RDDS equipment list, supplier, and daily rental charges

\begin{tabular}{|c|c|c|c|c|c|}
\hline Item & \multirow[t]{2}{*}{ Item Description } & \multirow[t]{2}{*}{ Qty. } & \multirow[t]{2}{*}{ Supplier } & \\
\hline & & & & \multicolumn{2}{|c|}{ Daily Costs } \\
\hline & CTDU & & & $\$ 30,000.00$ & $\$ 14,400.00$ \\
\hline 1 & Substructure and Mast System & 1 & Schlumberger - Dowell & & \\
\hline 2 & Jacking Frame & 1 & Schlumberger - Dowell & & \\
\hline 3 & CTDU Control Cabin & 1 & Schlumberger - Dowell & & \\
\hline 4 & $\begin{array}{l}\text { CT Reel Model } 3115 \text { with } \\
11,500 \text { feet of } 2^{*} \mathrm{CT}\end{array}$ & 1 & Schlumberger - Dowell & & \\
\hline 5 & $\begin{array}{l}\text { CT Reel Model } 3115 \text { with } \\
11.5 K^{\prime} \text { of } 2^{n} \text { CT, 7-42 P-CAP E-Line, } \\
\text { Pressure Bulk Head and Collector }\end{array}$ & 1 & Schlumberger - Dowell & & \\
\hline 6 & $\begin{array}{l}\text { S\&S } 800 \text { Injector head with } 80,000 \\
\text { pounds pull capacity }\end{array}$ & 1 & Schlumberger - Dowell & & \\
\hline 7 & CTDU Hydraulic Powerpack & 1 & Schlumberger - Dowell & & \\
\hline 8 & $\begin{array}{l}\text { Blowout Preventors - } \\
6-1 / 8^{\prime \prime} \text { Combination }\end{array}$ & 1 & Schlumberger - Dowell & & \\
\hline 9 & Blowout Preventors - $4.06^{*}$ Quad & 1 & Schlumberger - Dowell & & \\
\hline 10 & Riser and Cross-over set & 1 & Schlumberger - Dowell & & \\
\hline 11 & Tool Container & 1 & Schlumberger - Dowell & & \\
\hline 12 & Mud Handling Equipment - Lines & & Third Party & & \\
\hline 13 & Mud Fluid System & & Schlumberger - Dowell & & \\
\hline 14 & High Pressure Mud Pump & 1 & Schlumberger - Dowell & & \\
\hline \multicolumn{4}{|c|}{ Surface Drilling BHA } & $\$ 6,500.00$ & $\$ 2,000.00$ \\
\hline 15 & Drilling Connector & 2 & Schlumberger - Anadrill & & \\
\hline$\overline{16}$ & Motor 3.5" & 2 & Schlumberger - Anadrill & & \\
\hline 17 & Break-out table & 1 & Schlumberger - Anadrill & & \\
\hline 18 & Drill Bits - Tri-cone & 4 & Schlumberger - Reed & & \\
\hline 19 & Drill Pipe or Heavy Weight & 4 & Third Party & & \\
\hline \multicolumn{4}{|c|}{ Directional Drilling MWD BHA } & $\$ 15,000.00$ & $\$ 11,500.00$ \\
\hline 20 & VIPER* Assembly & 2 & Schlumberger - Anadrill & & \\
\hline 21 & 2-7/8" XP Motors & 4 & Schlumberger - Anadrill & & \\
\hline 22 & Drill Bits - Roller Cone, TSP \& PDC & 2 & Schlumberger - Reed & & \\
\hline \multicolumn{4}{|c|}{ Auxiliary Surface Equipment } & & \\
\hline 23 & Air Compressor & 1 & Third Party & & \\
\hline 24 & Generators & 2 & Third Party & & \\
\hline 25 & Lighting for night work & 10 & Third Party & & \\
\hline 26 & Accomodations & 1 & Third Party & & \\
\hline 27 & Tubular goods and hardware & & Third Party & & \\
\hline 28 & $\begin{array}{l}\text { Pipe handling equipment: slips, } \\
\text { tongs, slip collars, etc. }\end{array}$ & 1 & Third Party & & \\
\hline 29 & Fishing Tools & & Baker Oil Tools & & \\
\hline \multicolumn{4}{|c|}{ Total Daily Charge - Surface Drilling } & $\$ 48,000.00$ & $\$ 27,900.00$ \\
\hline \multirow{2}{*}{\multicolumn{4}{|c|}{ Total Dailv Charae - Directionai Driling }} & \multicolumn{2}{|c|}{+3 rd Party Charges } \\
\hline & & \multicolumn{2}{|c|}{ Total Daily Charge - Directional Drilling } & $\$ 47,000.00$ & $\$ 27,900.00$ \\
\hline \multirow{2}{*}{\multicolumn{4}{|c|}{ Event Mobilization/De-mobilization Charge }} & \multicolumn{2}{|c|}{+ 3rd Party Charges } \\
\hline & & & & Documented & Cost $+15 \%$ \\
\hline \multicolumn{6}{|c|}{$\begin{array}{l}\text { *Third party charges will be charged from the first mobilization day to the third day following } \\
\text { retum of equipment to the mobilization base. Item \#18 Drill Bits is called third party because they are } \\
\text { considered a consumable item. }\end{array}$} \\
\hline
\end{tabular}




\subsection{Timing and Contractual Considerations}

The time required for assembling the RDDS prior to deployment to an OSI location will depend to some extent on the level of activity of the oil industry. The system will be pieced together when the order for the equipment is made. Some system components such as the mast and substructure may be in high demand for other applications.

It is recommended that a call for assembly of the RDDS on a standby basis be made as soon as the OSI is approved. The stand-by charges would apply from the day the equipment is earmarked for an RDDS project to the time the unit is rigged-in and pressure tested. The operating charge would apply from the time the unit has been satisfactorily pressure tested to the time the well-head valve, or equivalent, is closed following the last run.

Additional discussions concerning logistics must involve the CTBT Organization and the State Parties to the Treaty.

\subsection{Personnel}

The RDDS unit will be set up in approximately 36 hours upon arrival at the desired location. The drilling will commence from the surface and will likely require a conductor casing to be driven. It is assumed that operations will be conducted around the clock and that two crews will be required, working a 12-hour shift each. The crews should consist of experienced personnel who have utilized the particular drilling equipment. Personnel are included in the daily rates listed in the above table .

The make-up of the crews is shown in Table 5.

Table 5.Personnel Required for a Twenty-Four Hour Drilling Project

\begin{tabular}{|l|c|c|l|}
\hline \multicolumn{1}{|c|}{ Position Title } & $\begin{array}{c}\text { Experience in CTD } \\
\text { (years min.) }\end{array}$ & $\begin{array}{c}\text { Number Required } \\
\text { on Location }\end{array}$ & Classification \\
\hline Drilling Engineer & 4 & 1 & FE-2 or GFE \\
\hline Rig Manager & 6 & 1 & SS-3 or GSS \\
\hline Driller/Service Supervisor & 4 & 2 & SS-2 \\
\hline Assistant Driller/Operator & 2 & 2 & SS-1 \\
\hline Pump Operator/Helper & 2 & 2 & ST-1 or ST-2 \\
\hline Mechanic & 2 & 1 & M-2 or higher \\
\hline Electrician & 0 & 1 & ET-2 or higher \\
\hline Mud Engineer & 1 & 1 & \\
\hline MWD Engineer & 1 & 2 & \\
\hline Directional Driller & 1 & 2 & \\
\hline Motor Specialist & 2 & 1 & \\
\hline
\end{tabular}




\section{TRANSPORTATION ISSUES}

It is assumed that the RDDS would be transported to the Inspected State Party by civilian aircrafts, under contracts with the CTBT Organization. There are a number of commercial aircrafts capable of moving the RDDS system. They include the Russian-built Antonov and Ilyushin series of longrange, heavy-lift freight transports, as well as the larger Boeing and Airbus equipment. Table 6 identifies the cargo dimensions and weight capacities for some of these aircrafts, while Figure 20 shows a Shaeffer 18-3/4 inch, 15,000 psi, XLS blowout preventer being loaded into an Antonov124. The unit weighed in excess of $55,000 \mathrm{lbs}$.

Table 6: Capacities of some possible cargo aircrafts to transport the RDDS

\begin{tabular}{|c|c|c|}
\hline Aircraft & $\begin{array}{c}\text { Maximum } \\
\text { Cargo Weight } \\
(\mathbf{k g})\end{array}$ & $\begin{array}{c}\text { Cargo Hold } \\
\text { Dimensions } \\
(\mathbf{L} * \mathbf{W} * \mathbf{H} \text { in meters })\end{array}$ \\
\hline $\mathrm{LL}-76 \mathrm{TD}$ & 45,000 & $20.0 \times 3.4 \times 3.46$ \\
\hline AN-124 & 120,000 & $36.5 \times 6.4 \times 4.4$ \\
\hline Boeing-747-400F & 113,000 & Various Hold Dimensions \\
\hline
\end{tabular}

The Antonov and Ilyushin aircrafts can be chartered from:

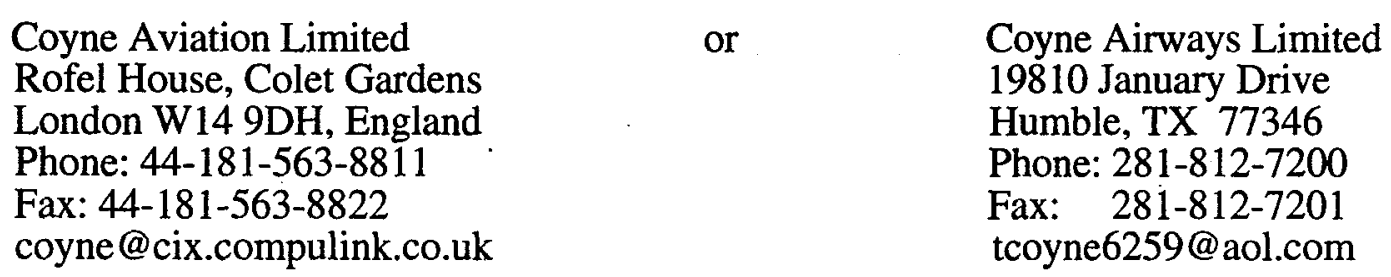

A request for quotation can be submitted through Coyne's web site: http://www.compulink.co.uk/ coyne-aviation

Cargo information can also be obtained from Nippon Cargo Airlines which charters the 747-200F:

Nippon Cargo Airlines (NCA)

Building \#79, North Boundary Road

JFK International Airport

Jamaica, NY 11430 USA ; Phone: 800-622-2746 ; Fax: 718-632-6418

The equipment modules must be small enough, once disassembled, to fit in cargo airplanes. The actual dimensions of the aircraft available will be the determining factor in the model type of some equipment to be used. The most versatile equipment would be skid mounted. Skids would be lighter for transport and more flexible in mounting configurations, which may change between locations and projects. 


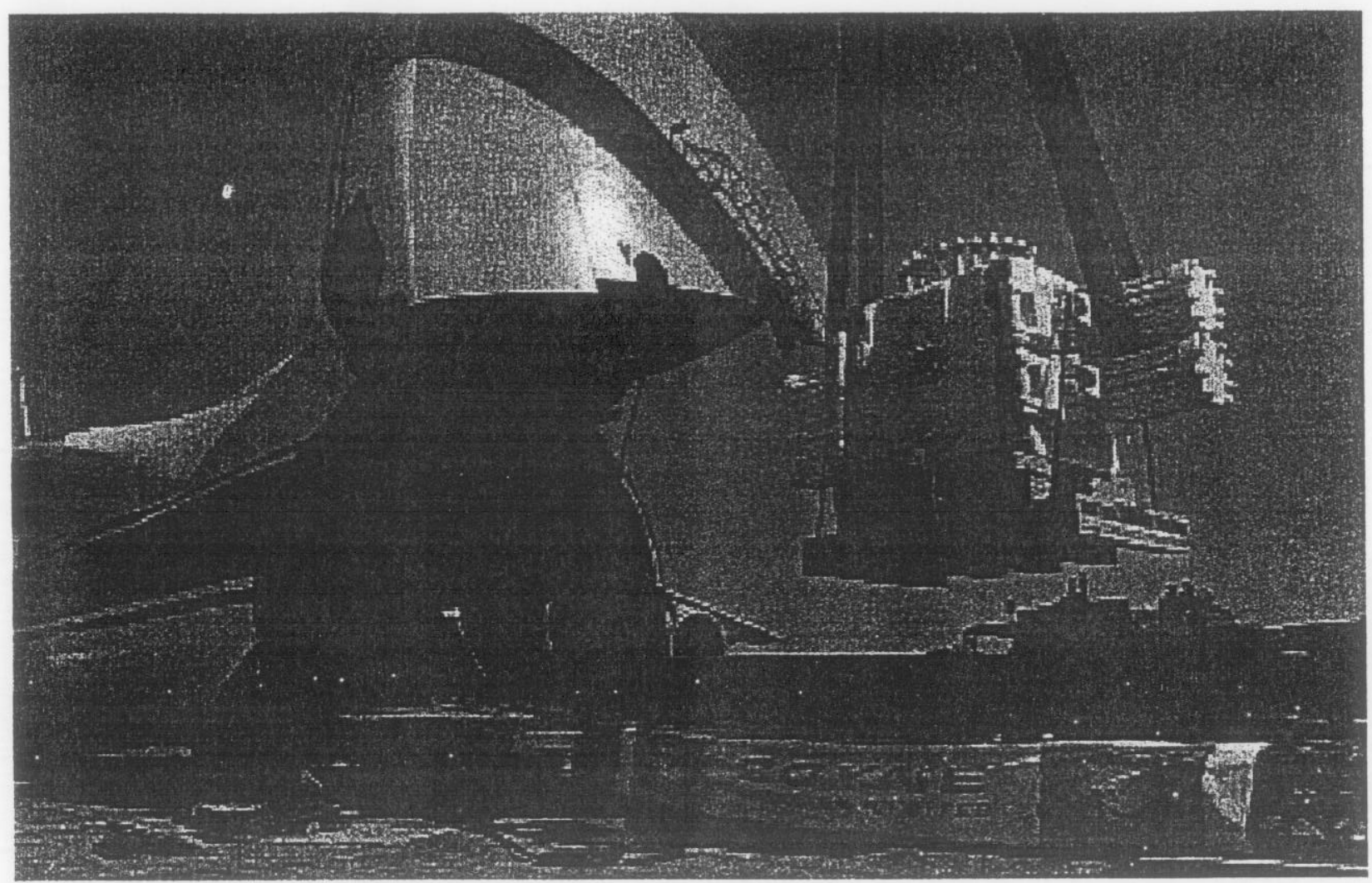

Figure 20. Loading of Large BOP on the AN-124 Transport (Provided by Coyne Airways Limited)

The RDDS coiled-tubing unit is mounted on a dual axle, drop deck trailer as illustrated in Figure 21. The trailer measures approximately 44 feet (13.4 meters) in length and weighs about 81,000 lbs $(36,775 \mathrm{~kg})$. The complete trailer can be shipped on the AN-124 aircraft. Alternatively, any of its elements (e.g., coiled-tubing reel, control cabin, etc.) can be removed from the trailer to reduce weight and height dimensions to allow other aircrafts to be used. For example, the Boeing-747 and the Ilyushin-76 could be used to transport any of the individual skids. The skids can then be placed onto the trailer and driven to the inspection site.

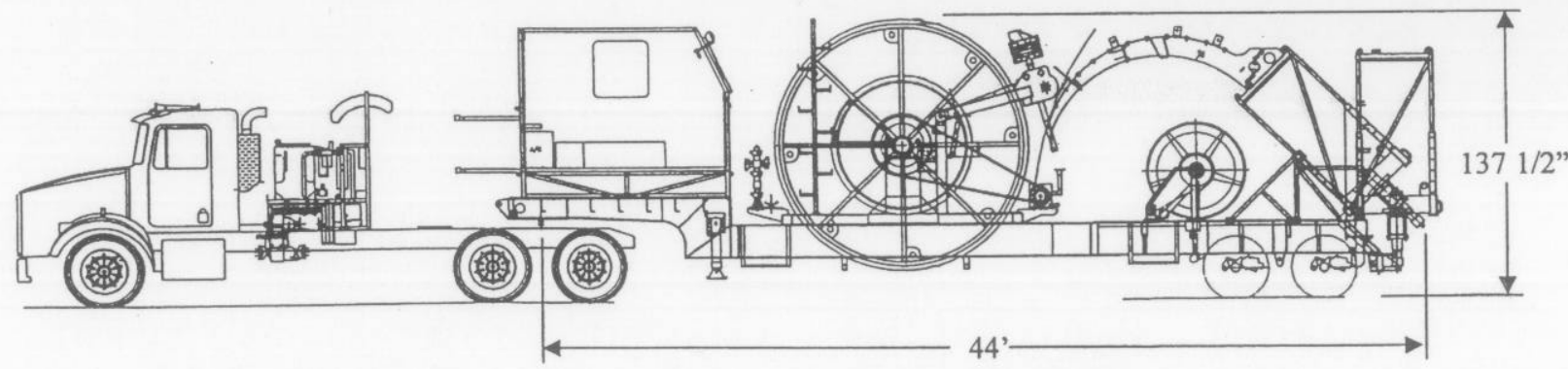

Figure 21. RDDS Coiled-tubing Trailer 
The IL-76 can operate from much shorter runways than the larger aircrafts, which could facilitate in-country deployment. Both the Antonov and Ilyushin have self-contained loading systems, which the Boeings do not have.

The mast on the mast/injector handling unit will have to be removed from its trailer and be shipped separately due to overall height limitations. Re-attachment of the mast onto the trailer is not expected to pose problems. Air shipment of masts of this size has successfully been done by Stewart \& Stevenson.

With the exception of the triplex mud pump, all components of the drilling fluid handling system can be shipped inside one 40-ft long freight container. The weights and dimensions of the container as well as the triplex pump and air compressor allow air shipment. The freight container and pumps can be placed onto one or two trailers (shipped separately or obtained in the host country) to move them to the site. The BHA components will be shipped with the coiled-tubing unit. The VIPER system electronics will be stored inside the control cabin during shipment while the mud motor(s) and drill bits can be placed inside steel lockers.

The exact aircraft requirements will depend on the equipment being shipped. The final list cannot be prepared until specific details about the drilling site are known. However, the system described in this report can be shipped on 3 AN-124 aircrafts. Table 7 shows a possible airlift scenario. Other supplies can be shipped with these loads, since the weight of the equipment does not exceed the cargo capabilities of the aircraft.

Table 7: Example of an airlift scenario

\begin{tabular}{|c|l|}
\hline \multicolumn{1}{|c|}{ Aircraft } & \multicolumn{1}{c|}{ Equipment } \\
\hline AN-124 No. 1 & $\begin{array}{l}\text { Coiled-Tubing Unit Trailer } \\
\text { Mud Cleaning System (shipped in 40 ft. container) } \\
\text { Tractor }\end{array}$ \\
\hline AN-124 No. 2 & $\begin{array}{l}\text { Drilling Mast Trailer } \\
\text { Drilling Mast. } \\
\text { Casing, Mud, Chemicals, etc. }\end{array}$ \\
\hline AN-124 NO. 3 & $\begin{array}{l}\text { Tractor } \\
\text { Triplex Mud Pump } \\
\text { H.P. Air Compressor (if needed) }\end{array}$ \\
\hline
\end{tabular}

Today there are $26 \mathrm{AN}-124$ operating as civilian cargo transports, worldwide. With advanced notice of 20 days or so it would not be a problem to mobilize 3 such aircrafts for OSI duty (C.T. Coyne, Houston, Texas, personal communication). Chartering an AN-124 for a 15,000-mile cargo round-trip may cost 200,000 to 400,000 dollars, depending upon whether the aircraft can be used to pick up loads for other clients at separate stops on the return trip from the OSI site to home base. 


\section{LABORATORY DRILLING TEST}

A major concern in the RDDS development is the type of rock to be drilled. Since the location and nature of a CTBT on-site inspection cannot be predicted, neither can the rock formation. However, it is logical to assume that an underground nuclear test will be conducted in competent rock. Because of the limited time allowed by the Treaty for OSI, it is important that the proposed system be capable of drilling at rates that will allow an adequate search.

To address questions concerning the drilling rate in typical competent rocks of medium strength Lawrence Livermore National Laboratory supplied 2.25 in. diameter rhyolite cores from the Nevada Test Site (NTS), for a drilling test. These cores were cemented into blocks of rock that fit the drilling test stand at Maurer Engineering's Drilling Research Center (DRC). Figure 22 shows one of the cores in a block as it is loaded into the drill stand. The core was drilled with a 1.75 in. diameter PDC Boart Longyear bit. The small diameter of core dictated the bit style since roller bits in this small size are not readily available. In actual practice a 3-7/8 in. bit would be used. If the formation can be drilled with PDC bits, they are the most logical choice as they will provide the highest penetration rates. This will be true even if the bits wear out quickly requiring frequent trips. The coiled-tubing rig will minimize trip time. However, PDC bits generally cannot drill hard rock. If the formation is too hard for PDC bits, than small roller bits will have to be used. Roller bits use carbide inserts and bit weight to crush the rock.

The core was drilled in the DRC drilling test stand, Figure 23 shows the core after the test. In this test the PDC bit drilled the Nevada core very fast. Figure 24 shows a graph of penetration rate vs. bit weight. These data show that the PDC bit drilled the rhyolite core at rates as high as $375 \mathrm{ft} / \mathrm{hr}$. Minimal wear was observed on the bit after these short tests.

Drilling data for the 1-3/4 in. bit must be extrapolated to see if an acceptable rate is feasible with a 3-7/8 in. bit at bit loads achievable with coiled-tubing. In addition the small bit was powered by the DRC test stand which, for this bit size, has effectively unlimited power. The actual drilling will be done with a mud motor. Data from one motor manufacturer's specification sheet show a maximum of $17 \mathrm{Hp}$ for a $2-7 / 8 \mathrm{in}$. motor.

To scale the 1.75 bit data, a minimum acceptable drilling rate needs to be established for the system. Assuming that $20 \mathrm{ft} / \mathrm{hr}$ is an acceptable rate, it will take approximately 10 days to drill $5000 \mathrm{ft}$. Since actual drilling often represents only 25 percent of the time on a rig, the total time to drill $5000 \mathrm{ft}$ will be 40 days. This is about half the maximum available time in an OSI . Because time-consuming side tracks may be required to locate a target, $20 \mathrm{ft} / \mathrm{hr}$ minimum is a reasonable goal.

Using the data from the drilling test (Figure 24) the specific energy to drill the Nevada Test Site core with the PDC bit can be calculated. Plugging the desired drilling rate and motor power into the following equation:

Rate-of-Penetration $=$ Power $/\{$ Area*Specific Energy $\}$

the specific energy needed to drill can be calculated. The result is approximately $10 \mathrm{Hp} / \mathrm{cuft} / \mathrm{hr}$. Referring to the graph in Figure 25, the weight on bit corresponding to this specific energy is determined to be approximately $1000 \mathrm{lbs}$. Extrapolating this on a per-area basis, the weight on bit for the larger bit will be $4900 \mathrm{lbs}$. An analysis using proprietary Maurer Engineering coiled-tubing buckling software shows that $4900 \mathrm{lbs}$ weight-on-bit (WOB) can be achieved in a well with a $1310-\mathrm{ft}$ radius of curvature. 


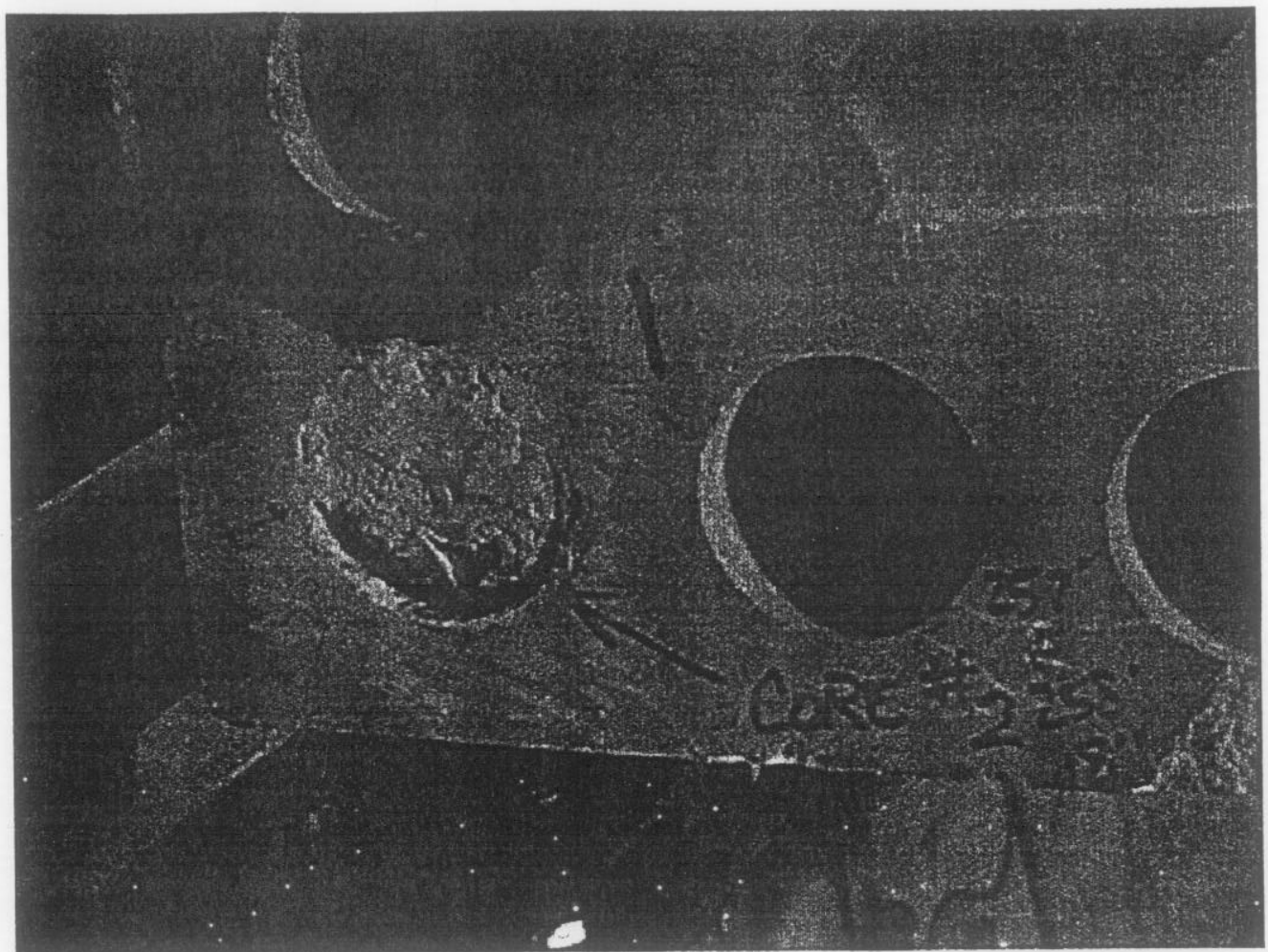

Figure 22: Nevada Test Site (NTS) rhyolite core cemented into drilling block

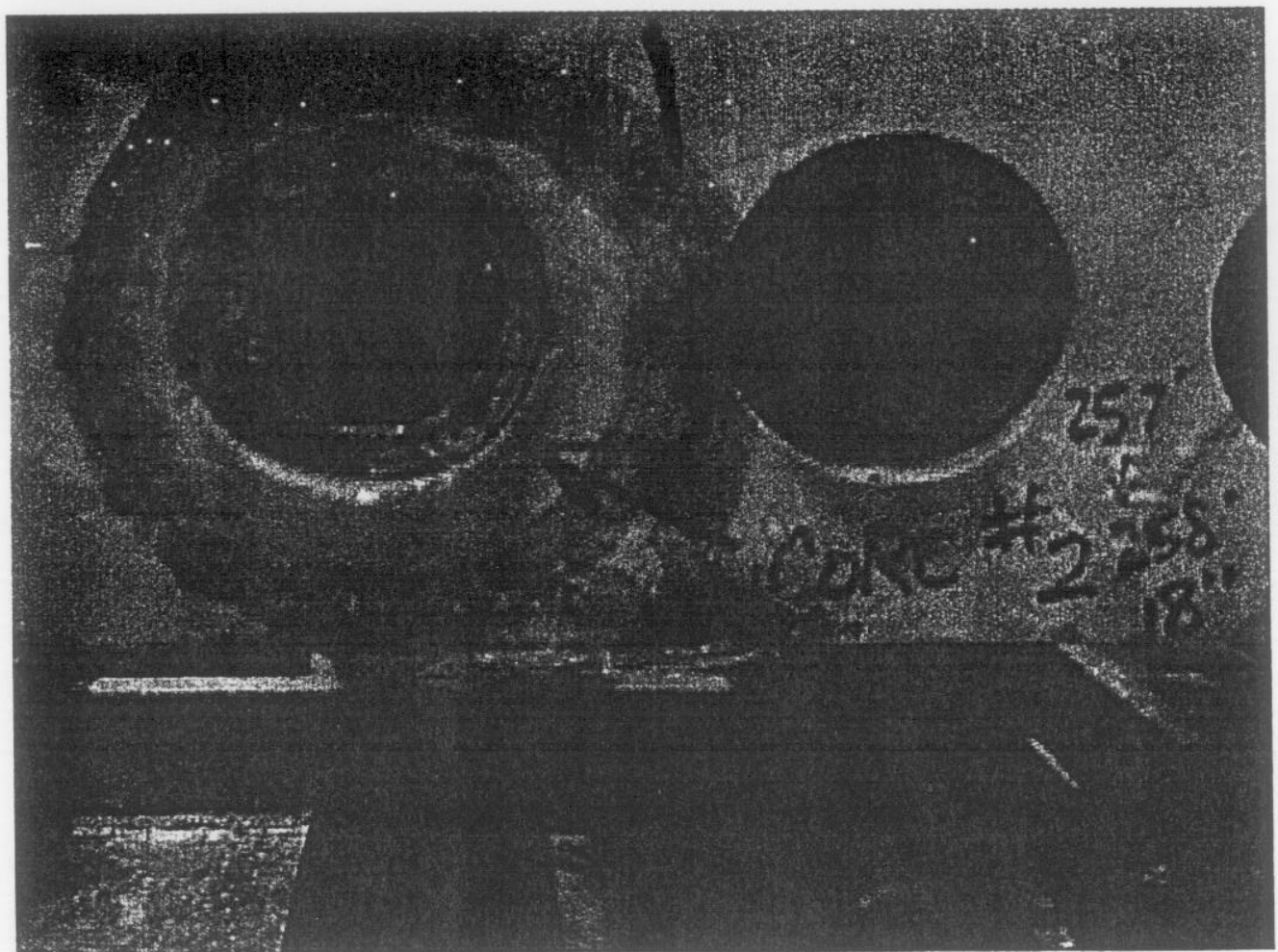

Figure 23: Drilled core 
ROP ys WOB

Navada Test Site Core Sample

RDDS

1.750 PDC B H

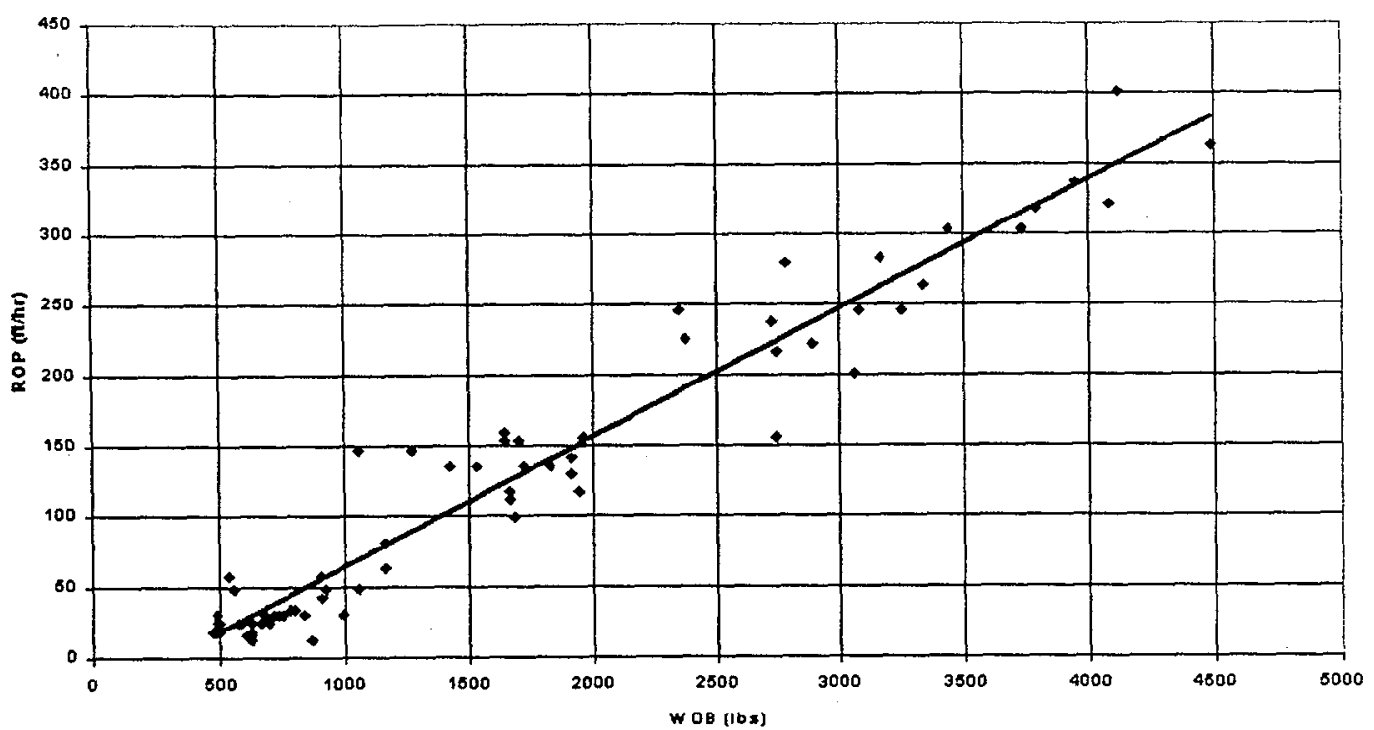

Figure 24: Penetration rate in NTS core

1-3/4 in. PDC B it

Nevad, Test S ite Core D rilling Test

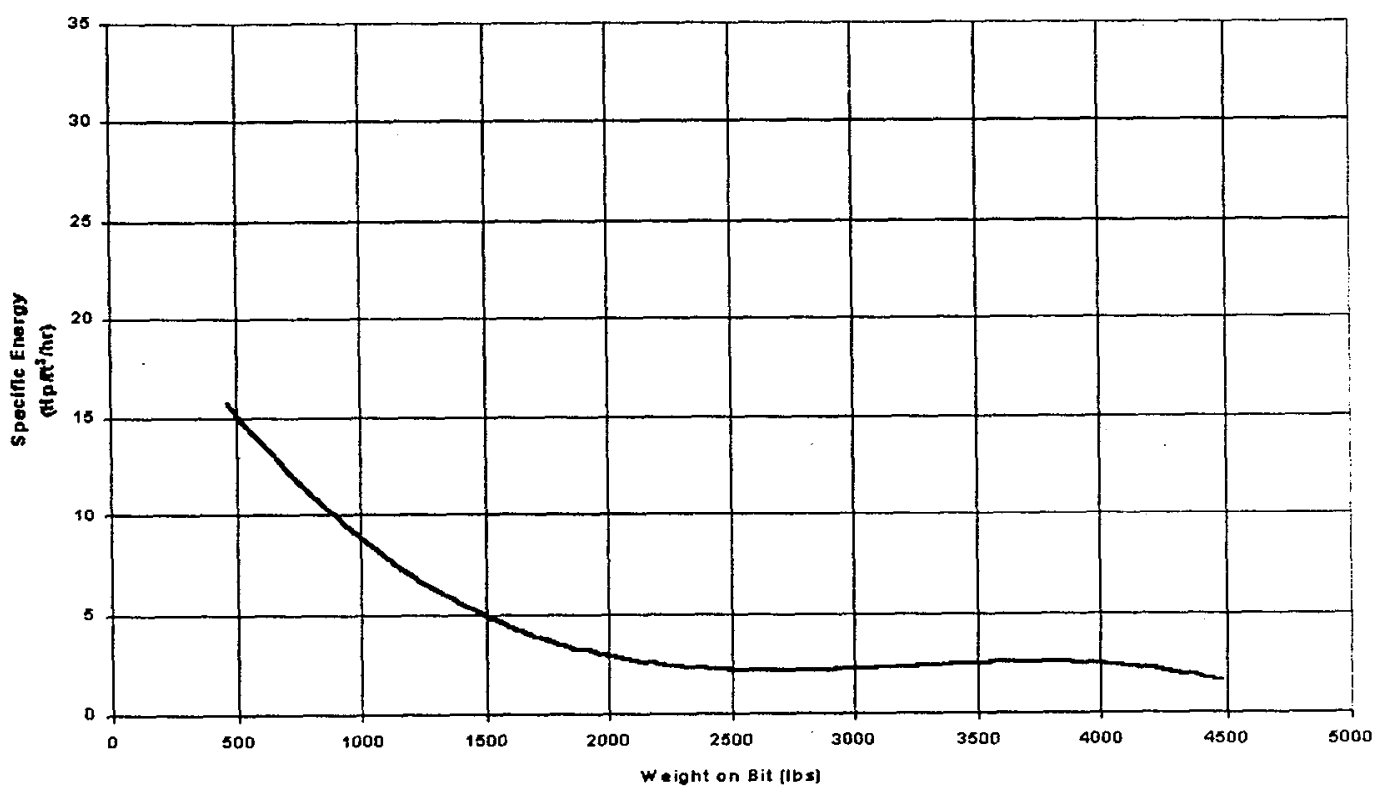

Figure 25: Specific energy vs. weight-on-bit for PDC bit in NTS rhyolite core

The above data and analysis show that it is feasible to achieve the desired penetration rate. However, the dynamics of drilling are very complicated and this is only a simple analysis. Additional data and experience can be obtained in a proof-of-concept drilling project, which is under discussion to be conducted at the Nevada Test Site. 


\section{REFERENCES}

1. Heuze, F.E. (1995) "Slimhole Drilling and Directional Drilling for On-Site Inspections Under a Comprehensive Test Ban - An Initial Assessment", Lawrence Livermore National Laboratory, UCRL-ID-121295, 12p., July

2. Maurer, W.C., Deskins, W.G., McDonald, W.J., Cohen, J.H., Heuze, F.E., and Butler, M.W. (1996) "Rapid Deployment Drilling System for On-Site Inspections Under A Comprehensive Test Ban - Preliminary Engineering Design", Report from Maurer Engineering, Houston, TX, to Lawrence Livermore National Laboratory, UCRL-CR-125259, 55p., Sept.

3. Fontenot, R., Shakir, S., Heuze, F., and Butler, M. (1998) "Development of a Bottom-Hole Gamma-Ray Diagnostic Capability for High-Level Environments, During CTBT On-Site Inspection Drilling", Report from Schlumberger-Anadrill, Houston, TX, to Lawrence Livermore National Laboratory, UCRL-CR-130663, 7p., May

4. Heuze, F. E. (1998) "Rock Testing Equipment in the Context of CTBT On-Site Inspections", Lawrence Livermore National Laboratory, UCRL-ID-129926, 12p., March.

\section{ACKNOWLEDGMENTS}

This project was supported by the LLNL CTBT Program, with funding from the U.S. Department of Energy's Office of Non-Proliferation and National Security, NN-42, under contract W-7405ENG-48.

We are grateful to Michael Butler, Donald Felske, and Jerry Sweeney of LLNL for their constructive comments, and to Sabrina Fletcher and Susan Uhlhorn for their editorial contributions.

The LLNL CTBT Program Leader is Jay Zucca. 